\title{
DIONYSIUS AREOPAGITES: A CHRISTIAN MYSTICISM?
}

\section{Introduction: A Controversial Figure}

The mysterious author who wrote under the name of Dionysius the Areopagite sometime around the turn of the sixth century has been the subject of theological and scholarly controversy for half a millenium. ${ }^{1}$ With a few recent exceptions, this controversy has been limited to the Christian West. It began properly with Martin Luther's explicit dismissal of «Dionysius» (whom henceforth I shall refer to without the inverted commas) as plus platonizans quam christianizans, «more a Platonist than a Christian», and his warning to «stay away from that Dionysius, whoever he was!» I am myself expert in neither the Reformation generally nor Luther in particular, but I think it not inaccurate to say that he read Dionysius as perhaps the advocate par excellence of a theologia gloriae, which is to say, a theological perspective which effectively makes superfluous the Incarnation and atoning death of God the Word, and which does so because it assumes that the human mind of itself is capable, at least in potential, of achieving direct contact with the deity. The great doctor of the Reform saw this pernicious attitude, so in opposition to his own theologia crucis, as especially embodied in the little Dionysian treatise, The Mystical Theology, which he read as an example less of truly Christian piety than of an appeal to the autonomous human intellect, hence: «Shun like the plague that Mystical Theology and other such works!» Ever since Luther, though here I should add that I am over-simplifying somewhat, Dionysius has been by and large a «non-starter» for Protestant theology and devotion, while Protestant scholarship, in so far as it deals with him at all, remains generally — or even emphatically — unsympathetic. ${ }^{2}$

\footnotetext{
${ }^{1}$ I will be referring to the Greek text of Dionysius in two editions, $P G 3$, with the column numbers, and, in parenthesis, the page and line numbers of the recent critical edition: Corpus Dionysiacum. Vol. I: De divinibus nominibus / Ed. B. R. SuchLA (Berlin-New York, 1990), and Corpus Dionysiacum, Vol. II, containing the rest of the corpus, including the treatises on the hierarchies, the Mystical Theology, and the Epistles, ed. by G. HeIL and A. M. Ritter (Berlin-New York, 1991). Unless otherwise stated, I shall be using the flowing and elegant — though theologically flawed - PseudoDionysius: The Complete Works / Tr. C. LiubHeID, ed. P. E. Rorem (New York, 1987).

${ }^{2}$ On the Protestant reception, see the admirable summary essay by K. FroEHLICH, Pseudo-Dionysius and the Reformation of the Sixteenth Century // Pseudo-Dionysius: The Complete Works... 33-46.
} 
The Roman Catholic approach to the Areopagite is somewhat different. During the Middle Ages, from the twelfth and especially the thirteenth centuries on, he was widely popular, even sensationally so. St. Thomas Aquinas, so I understand, quotes him nearly as often as Scripture, something over a thousand times. Apologists for papal authority saw in his treatises on the hierarchies, The Celestial and The Ecclesiastical Hierarchy, apostolic-era support for the vision of church order they were seeking to establish and defend. The mystics of the late medieval Rhineland and of England (e.g., Meister Eckhardt and the author of The Cloud of Unknowing), and later on the great spiritual writers of Counter-Reformation Spain, such as SS Theresa of Avila and especially John of the Cross, were likewise well-disposed to Dionysius, especially, once more, to his Mystical Theology. Yet, it is also the case that Dionysius was never approached so-to-speak in toto by any of his medieval and post-medieval, Western admirers (or detractors, for that matter). Rather, bits of his thought - for example, the appeal of his long treatise on The Divine Names, with its exitus-reditus scheme of creation and return to God, to Thomas and other masters of speculative divinity, or the notion of hierarchy to the canonists, or the Mystical Theology to the enthusiasts of mystical piety - were broken-off and applied, as it were, piecemeal to the several interests of his different admirers. Put briefly, it is an effectively fractured Dionysius that we find at the end of the Western Middle Ages, with larger or smaller chunks of his oeuvre tacked on to - or, as with Aquinas, assimilated with magisterial elegance into - an already well-established and secure theological Gestalt. ${ }^{3}$ With the Reformation and its aftermath, Catholic attention shifts into a defensive mode, and the Areopagite becomes one element among many — though not a very important one — in the to and fro of debate over the sources and witnesses to tradition. Catholic interest at this point is focused chiefly on defending what we now recognize as indefensible: the apostolic-era provenance of these writings. The advent of modern scholarship, particularly the past century or so, has meant that Catholic scholars, with some notable exceptions, have become generally much more ambivalent, and on occasion actively hostile, toward the Corpus Dionysiacum. ${ }^{4}$

What we do not find practically anywhere is much of any true sense of the Dionysian writings as a whole, i.e., what they were, and what they were try-

${ }^{3}$ See J. LeCLERCQ, Influence and noninfluence of Dionysius in the Western Middle Ages // Pseudo-Dionysius: The Complete Works... 25-34; A. Louth, Denys the Areopagite (Wilton, 1989) 121-126; IDEM, The Influence of Denys the Areopagite on Eastern and Western Spirituality in the 14th Century // Sob/ECR 4 (1982) 185-200; and P. E. Rorem, Pseudo-Dionysius: A Commentary to the Texts and an Introduction to their Influence (Oxford-New York, 1993), which touches throughout on Dionysius' appropriation by the medieval Latin West, if from a perspective not at all friendly to Dionysius himself.

${ }^{4}$ See the scholars discussed in the section following. 
ing to say, and to whom. I shall argue in the essay following that the chief reason we find no conflict over them in the Christian East, or at least not until the influence of Western scholarship during the twentieth century, is because that was their original milieu. Dionysius is an Eastern Christian writer and, moreover, a monastic one. ${ }^{5}$ He wrote to and for monks, and monks in turn Eastern ones, at least - have always recognized that fact. They understood him then, and in general they still understand him now, because he and they shared common concerns and a common theological, liturgical, and spiritual Gestalt. This is then my thesis statement for the remarks which follow, and which I offer as a kind of introit into the «mind» of the Dionysian corpus. ${ }^{6}$

\section{Three Question Marks and Three «Nots»: A Brief Look at over a Century of Dionysian Scholarship}

The title of my essay, «Dionysius Areopagita: a Christian mysticism», question mark, should therefore really be followed by three question marks. It is widely, though not universally, held that the author of the Corpus Dionysiacum was not only not the Dionysius the Areopagite of Acts 17:34, who shows up as one of the very few prizes carried off by St. Paul following the latter's sermon at the altar of the «Unknown God» on Mars Hill, but that he was also neither really a Christian, nor a mystic.

With the first «not» I must agree. The first clearly datable reference to the Dionysian corpus comes to us from the minutes of the colloquium, between opponents and defenders of the Council of Chalcedon, convoked by the Emperor Justinian in 532 in order to put an end to the quarrel over christology, or at least so the emperor hoped. The hope was in vain, as it turned out, but in the course of discussion the anti-Chalcedonians cited one Dionysius the Areopagite who, they said, had lent apostolic-era approval to their position on the single nature of the incarnate Word by writing in his fourth epistle of Christ's «single, divine-human activity». Metropolitan Hypatius of Ephesus, speaking for the pro-Chalcedonian side, replied tartly that, since none of the earlier fathers had mentioned this «apostolic source», he was not about to admit it

${ }^{5}$ This is a point not generally appreciated in the scholarly literature. There is one only article, to my knowledge, devoted to Dionysius' concept of the monk: R. RoQuEs, Éléments pour une théologie de l'état monastique chez Denys l'Aréopagite // Théologie de la vie monastique (Paris, 1961) 283-314, which is excellent as a summary of the Dionysian text, but entirely insensitive to its roots in Christian Syria. I must confess that I am nearly unique in drawing attention to the latter, and quite unique in stressing it as I do.

${ }^{6}$ It is also a kind of offering to my father in God, Aimilianos, retired abbot of the monastery of Simonos Petras, Mount Athos, who provided me with my essential insights into the Dionysian mind. 
into evidence, either. ${ }^{7}$ In spite of the good Metropolitan's hesitations, Dionysius proved to be an immediate «hit» in the Chalcedonian and even Nestorian (!) worlds as well. The terms he invented, such as most notably the word, «hierarchy», and the phrase, «mystical theology», spread with remarkable speed. ${ }^{8}$ Ten or twenty years after the colloquium, Bishop John of Scythopolis in Palestine would write the Scholia on the corpus which cemented its reputation and which have accompanied it ever since..$^{9}$ Even sooner, perhaps contemporaneously with or even a little before the colloquium, a certain Sergius of Reshaina would translate Dionysius into Syriac, where he immediately shows up in the writings of the rather strange, Syrian Christian mystic, Stephen bar Sudaili. ${ }^{10}$ In the following century the greatest theologian of the later Byzantine era, the monk and saint Maximus the Confessor, would hold Dionysius in the highest regard. The Areopagite appears everywhere in Maximus' oeuvre, as he does in that of John Damascene a century later. ${ }^{11}$

${ }^{7}$ Acta Concilium Oecumenicorum / Ed. E. SchwarTz (1914) IV.2, 173:13-18.

${ }^{8}$ See, e.g., J. Stiglmayr, Über die Termini Hierarch und Hierarchia // ZKT 22 (1898) 180-187.

${ }^{9}$ See B. R. Suchla, Die sogennanten Maximus-Scholien des Corpus Dionysiacum Areopagiticum // NAG (1980) 31-66; IDEM, Eine Redaktion der griechischen Corpus Dionysiacum im Umkreis des Johannes von Skythopolis, des Verfassers von Prolog und Scholien. Ein dritter Beitrag zur Überlieferungsgeschichte des Corpus Dionysiacum // NAG (1985) 1-18; and, most recently and accessibly, P. E. RoREM, J. C. Lamoreaux, John of Scythopolis and the Dionysian Corpus: Annotating the Areopagite (Oxford, 1998) Esp. 7-45.

${ }^{10}$ On the Syriac transmission of Dionysius, see J.-M. Hornus, Le corpus dionysien en Syriaque // ParOr 1 (1970) 69-93; G. WIESSNER, Zur Handschriftenüberlieferung der syrischer Fassung des Corpus Dionysiacum // NAG (1972) 165-216; and again Suchla, Die sogennanten Maximus-Scholien... 35-36. On Sergius of Reshaina and Dionysius, see P. SHERwood, Sergius of Reshaina and the Syriac Versions of the Pseudo-Dionysius // SE 4 (1952) 174-184; and for a French translation of Sergius' own remarks on his translation, IDEM, Mimro de Serge de Rešayna sur la vie spirituelle // OrSyr 5-6 (1960) 433-457, (1961) 95-115 and 121-156. On Sergius as possible author of the Areopagitica, see R. A. Arthur, A New Interpretation of the Context and Purpose of the Pseudo-Dionysian Corpus. Unpub. D. Phil. dissertation (Kings College, University of London, 1998) Esp. 123-127 and 191-192; and as arguing for a close relation between Stephen bar Sudaili and Dionysius, IDEM, A Sixth-Century Origenist: Stephen bar Sudaili and his Relationship with Pseudo-Dionysius // SP XXXV (2001) 369-373. For a translation and introduction to Stephen bar Sudaili, see F. S. MARsh (ed. and trans.), The Book which is called The Book of the Holy Hierotheus with Extracts from the Prolegomena and Commentary of Theophilus of Antioch and from the «Book of Extracts» and other Works of Gregory Bar-Hebraeus (London, 1927).

${ }^{11}$ On Dionysius' presence in Maximus, see L. Thunberg, Microcosm and Mediator: The Theological Anthropology of Maximus the Confessor (Chicago, 1995²) throughout, though esp. 192-195, 408-410, 413-418, 423-426; P. M. BLOwERS, Exe- 
If 532 provides the ad quem of the Areopagitica, the a quo is usually set at 487, the death of the pagan Neoplatonist philosopher, Proclus Diadochus. Here we arrive at the question mark over Dionysius' Christianity. An anonymous scholiast of Dionysius had noticed, along with others, the strong resemblances - not to say occasional word for word matches — between Proclus and the disciple of St. Paul, Dionysius. The scholiast argued that the pagan had cribbed from the Christian master. ${ }^{12}$ Over thirteen hundred years later, in 1895 to be exact, two German scholars, Josef Stiglmayer and Hugo Koch, simply reversed the relationship: Dionysius was dependent on Proclus, not only in the former's account of evil in Divine Names IV:18-33, where the match is nearly exact, but, as Koch was successfully to demonstrate five years later, in many other places as well. ${ }^{13}$ Modern scholarship on Dionysius dates properly from these two German scholars. The discussion ever since has focused on the nature of Dionysius' undoubted relationship to late Neoplatonism and, following from that, the matter of his ostensible allegiance to the faith of St. Paul and the Gospels. To borrow from Tertullian: given the massive presence of «Athens» in Dionysius' thought, was there any real room aside from purely verbal acknowledgements — for «Jerusalem»? Put another way: to what degree was (and is) late Neoplatonism compatible with Christianity, and how successful was Dionysius in making the match?

These questions also mark the end of scholarly consensus, as is very clear from the various candidates who have been advanced over the past hundred years for the authorship of the corpus. They range from Orthodox writers to «Monophysites» to pagans, though none of these proposals has ever succeeded in persuading anyone save its particular scholarly advocate. ${ }^{14}$ We simply

gesis and Spiritual Pedagogy in Maximus the Confessor: An Investigation of the Quaestiones ad Thalassium (Notre Dame, 1991) Esp. 11-12, 184-185, 252-253; and the two essays by Y. DE ANDIA on Maximus, and on John Damascene by A. LouTH, in Y. DE Andia (ed.), Denys l'Aréopagite et sa posterité en Orient et en Occident (Paris, 1997).

${ }^{12} P G$ 4. 21D.

${ }^{13}$ H. Koch, Proklus als Quelle des Pseudo-Dionysius Areopagita in der Lehre von Bösen // Ph 54 (1895) 438-454; IDEM, Pseudo-Dionysius Areopagita in seinen Beziehungen zum Neuplatonismu und Mysterienweses (Mainz, 1900); and J. STIGLMAYR, Der Neuplatoniker Proklos als Vorlage des sog. Dionysius Areopagita in der Lehre vom Übel // HJ 16 (1895) 253-273 and 721-748. See also the latter's equally important article, Das Aufkommen der Ps.-Dionysischen Schriften und ihr Eindrungen in die christliche Literatur bis zum Lateranconcil 649. Ein zweiter Beitrag zur Dionysius Frage // IV Jahresbericht des offentlichen Privatgymnasiums an der Stelle matutina zu Feldkirch (Feldkirch, 1895), which places the Dionysian corpus in SyroPalestine at the turn of the sixth century.

${ }^{14}$ For a listing of the various attempts to identify Dionysius with one or another figure in pagan or Christian antiquity, see A. Golitzin, Et introibo ad altare dei: The

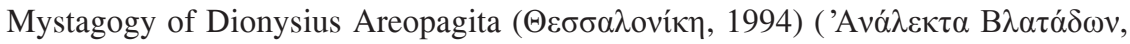
59) 24-25. 
do not know who Dionysius was, nor, barring new evidence, will we ever know. We do know roughly the region which he writes from, Syria-Palestine, but we cannot pinpoint it more exactly. These factors, the anonymity, the only very approximate location, and the near half-century between 487 and 532, make it next to impossible to agree - borrowing a phrase from biblical scholarship - on Dionysius' Sitz im Leben. Why was he writing at all? for whom? What, as we say nowadays, was his agenda? To these I would add: why was he so readily and enthusiastically received in the Christian East?

The answers to my questions differ among scholars along lines that match the spectrum of proposed authors. For those of Reformed or Lutheran background, from Bishop Anders Nygren in the 1930's to Professor Paul Rorem in the 80's and 90's, Dionysius is at best a failed Christian, if not a pagan wolf in Christian sheep's clothing. Nygren, indeed, sees in the reception of the corpus proof that the Christian world had already and for far too long been drinking much too deeply at Plato's well. That the Medieval West would follow the East - much later and a little disjointedly (recall my remarks above) - in receiving Dionysius with, if anything, even greater enthusiasm, served the Swedish bishop as proof for the need for Luther's rediscovery of Galatians and the Reformation's recovery of Pauline Christianity. ${ }^{15}$ While this confessional, not to say polemical, current is nearly invisible in Professor Rorem's recent works, it is nonetheless the case that both men, together with nearly all the Protestant scholarship of the sixty years between the two of them, understand Neoplatonist philosophy and Christian faith as mutually antithetical. ${ }^{16}$

Catholic and - to the extent they exist - Orthodox scholars display more variety. Hans Urs von Balthasar and Louis Bouyer, on the Catholic side, with Vladimir Lossky, Andrew Louth, and John Romanides for the Orthodox, applaud the Corpus Dionysiacum (which I shall refer to henceforth as $C D$ ) as both profound in itself and faithful to prior tradition. ${ }^{17}$ Another

${ }^{15}$ A. Nygren, Agape and Eros / Trans. P. S. WATson (Philadelphia, rev. ed., 1953) Esp. 576-593, where Dionysius appears as the climax of the betrayal of Christianity to Platonism initiated by the 2 nd and 3rd century Alexandrians.

${ }^{16}$ Most of Professor RoREM's works are studiously neutral, at least in their formal presentation. He does, however, specifically mention his belonging to the Lutheran communion in Pseudo-Dionysius: A Commentary... 239, and has recently expressed himself more openly on Dionysius from a Lutheran perspective in Martin Luther's Christocentric Critique of Pseudo-Dionysian Spirituality // LuthQ 11 (1997) 291307, and Empathy and Evaluation in Medieval Church History and Pastoral Ministry: A Lutheran Reading of Pseudo-Dionysius // PSB 19.2 ns (1998) 99-115. My thanks to the author for kindly sending me an offprint of the latter essay.

${ }^{17}$ H. von Balthasar, Herrlichkeit: eine theologische Aesthetik (Einseideln, 1964) II. 228-289; L. BouYER, The Spirituality of the New Testament and the Fathers / Tr. M. RYAn (New York, 1982) 384-392; V. N. LossKy, La notion des «analogies» chez 
Catholic, Rene Roques, together with the Orthodox scholars, Georges Florovsky and John Meyendorff, maintain certain reservations, particularly with regard to the Dionysian hierarchies and christology. ${ }^{18}$ The Belgian Jesuit, Jean Vanneste, forty years ago, and, very recently, Ysabel de Andia of the Sorbonne see in Dionysius less the Christian than the pagan philosopher, even metaphysician, while a Hungarian Orthodox scholar, Istvan Perczel, has just published a series of articles arguing for the Areopagite as a cunning, deliberately deceptive heretic of the most extreme sort. ${ }^{19}$ It was Vanneste, however, who raised in sharpest form the third question mark over my title today, the matter of Dionysius' mysticism - or, rather, the lack of it. For Vanneste, the Areopagite is not a mystic, but a religious philosopher who is less interested in the details of a «vital experience» than in «the exact and tight articulations of [his] conceptual structure». ${ }^{20}$ The very symmetry and rigor of his thought, a point which both Vanneste and Professor Rorem bring out in their analyses of, in particular, the Mystical Theology (henceforth MT) argue for them against the latter treatise as the report or fruit of any actual experience.

How then am I to reply to the question marks, with which I do not agree, over Dionysius' Christianity and mysticism? Perhaps I might begin by quoting one of the few reports of direct experience which we do find in this mysterious author, and where we may also be fairly certain that he is not writing in order to support his pseudonym. Here he is speaking of his own baptism:

Denys le pseudo-Aréopagite // AHDL V (1931) 179-209; and throughout his epochal book, The Mystical Theology of the Eastern Church / Tr. A. Moorhouse (London-Cambridge, 1968); Louth, Denys the Areopagite...; J. Romanides, Notes on the Palamite Controversy and Related Topics // GOTR 6.2 (1960/61) 186-205 and (1963/64) 225-270.

${ }^{18}$ R. Roques, L'Univers dionysien (Paris, 1954); G. Florovsky, The Byzantine Ascetic and Spiritual Fathers. Vol. X of The Collected Works of Father Georges Florovsky (Belmont, 1987) 204-229; J. MEYENDORFF, Christ in Eastern Christian Thought (Washington, 1969) 75-84.

19 J. Vanneste, Le Mystère de Dieu (Brussels, 1959); IDEM, Is the Mysticism of Pseudo-Dionysius Genuine // IPQ 3 (1963) 286-306; Y. DE ANDIA, Henôsis: l'union à Dieu chez Denys l'Aréopagite (Leiden-Köln, 1996), though the monograph is not so negative in tone regarding Dionysius' fundamental Christianity as the author's article (cited above, n. 11), and is most commendably sensitive to his patristic background, thus see, e.g., 303-373 for an impressive assembly of patristic parallels to Dionysius' treatment of Moses in Mystical Theology I.3; I. Perczel, Le Pseudo-Denys: lecteur d'Origéne // Origeniana Septima: Origenes in den Auseinandersetzungen des fierten Jahrhuderts / Ed. W. A. BIENERT, U. KüHNEWEg (Leuven, 1999) 674710; IDEM, Une théologie de la lumière: Denys l'Aréopagite et Évagre le Pontique // REAug 45.1 (1999) 79-120.

${ }^{20}$ Vanneste, Is the Mysticism of Pseudo-Dionysius Genuine?... 290. 
It was this sacrament which first gave me [the power] to see, and, by means of its ruling light, to be led up in light to the vision of the other sacred things. ${ }^{21}$

Elsewhere in the same treatise, the Ecclesiastical Hierarchy (henceforth $E H$ ), he returns to this idea on at least two other occasions. In chapter 2 he speaks of baptism supplying a spiritual capacity for the sight or vision of the divine light informing Christian worship. ${ }^{22}$ In chapter 3 , while discussing the formation of catechumens in the «womb» of the Church's «Liturgy of the Word», he notes that, because they are not yet fully formed, they have not yet received «the organs» capable of spiritual sight which are given in baptism. ${ }^{23}$ The at least implicit doctrine of the «spiritual senses» here, associated with and indeed given by the Christian sacrament, recalls Origen of Alexandria 300 years before, as well as much of the ascetic literature in the intervening centuries, e.g., in Evagrius of Pontus $(\dagger 399)$ and in the late fourth century Macarian Homilies. I shall return to the latter a bit further on, but for now I would like to stress, first, that Dionysius, at least in the $E H$, places repeated emphasis on the «divine birth» of baptism, and thus, second, appears to establish the context of whatever «vision» or «experience» of God he may ultimately espouse firmly within the liturgical and sacramental life of his local church.

With this assertion we come up against another question which has greatly exercised Dionysian scholarship: the coherence or, more precisely, the perceived incoherence of the corpus. On the one hand, we have the apparent advocacy of direct encounter and union with God which we find in the MT's account of Moses' ascent, and which Dionysius repeats in at least a dozen passages in his longest treatise, the Divine Names (henceforth $D N$ ). On the the other hand, in the two treatises on the hierarchies, the Celestial Hierarchy (henceforth $\mathrm{CH}$ ) and $\mathrm{EH}$, we find a repeated insistence on what Fr. Georges Florovsky has referred to as «the staircase principle», ${ }^{24}$ that is, that knowledge of divine things is necessarily mediated. It percolates downwards from the orders of angels around the divine throne through the lower angelic ranks to our hierarchy, to our sacraments and clergy and, finally, through the latter, to the baptized laity. In terms of Dionysius' four treatises, what do the $D N$ and especially the $M T$ have to do with his meditations on the hierarchies of men and of angels? What is the relation, if any, between the public worship of the Christian Church, its sacraments and ordained ministers, and the direct encounter with God in «the darkness of unknowing»? And, relatedly, what is

\footnotetext{
${ }^{21}$ EH 3.1, 425AB (80:1-4).

${ }^{22}$ EH 2.3.3, 400AB (74:15-75:9).

${ }^{23}$ EH 3.3.6, 432D-433A (85:11-21): literally, «the [organs] capable of receiving» light, ta dektika.

${ }^{24}$ Florovsky, Byzantine Ascetical and Spiritual Fathers... 221.
} 
the connection between his ostensible profession of Christian faith and the obvious use he makes of the late Neoplatonists?

The answers different scholars give once again vary considerably. Fr. Vanneste, and to a lesser degree René Roques, suggested a bifurcation in Dionysius' thought between the «economy» or «theurgy» of the hierarchies, and the «theology», i.e., matters pertaining to the divinity itself, of the $D N$ and $M T .^{25}$ Once the Areopagite's thought is thus divided, there is considerable room allowed - and, in Vanneste's case, insisted upon - for his non-Christian Neoplatonism, and so for the autonomy of the human intellect in its inherent capacity for a «natural union» with divinity that is independent of the Christian appurtenances of scripture, sacraments, and, indeed, of Christ Himself and the Holy Trinity. ${ }^{26}$ More recently, Professor Rorem has argued in several books and articles that, to the contrary, Dionysius' thought is altogether united and coherent, but it is this very coherence which Rorem understands as giving the lie to any protestations of Christianity in the corpus. According to his reading, the apophatic «methodology» of the $M T$ lies at the center of the corpus and properly precedes the reading of the $\mathrm{CH}$ and $\mathrm{EH}$, an ordering of the treatises ( $D N, M T, C H, E H)$ which is reflected in Professor Rorem's edition of the English translation of the $C D$ for the Paulist Press series, Classics of Western Spirituality . Placed thus as, in Rorem's words, the «methodological prologue» to the reflections on scripture and liturgy in the $\mathrm{CH}$ and $\mathrm{EH}$, the $M T$ acts as a kind of solvent, burning away the outward Christian trappings in order to reveal, beneath them all, the «timeless» relationship obtaining between the divine as cause and the intellect as effect. ${ }^{27}$ Professor Rorem there-

${ }^{25}$ RoQues, L'Univers dionysien... 29-30; Vanneste, Mystère de Dieu... 32-35.

${ }^{26}$ VAnNeste, Mystère de Dieu... 182-217, perhaps esp. 195-197. Cf. also, on a «natural mysticism» in Dionysius and the late Neoplatonists, J. R. Rist, Mysticism and Transcendence in Later Neoplatonism // Hermes 92 (1964) 213-225, here 219. I am happy to add, however, that Professor Rist has subsequently withdrawn this accusation.

${ }^{27}$ The adjective, «timeless», i.e., as indicating the fundamentally «natural» and philosophical or ahistorical — as opposed to Christian — thrust of Dionysius' thought, appears often in Professor Rorem's many works. See, e.g., RoREM, Pseudo-Dionysius: A Commentary... 120, 123, 125, 171, and 239; and on the $M T$ as a «methodological prologue» to the treatises on the hierarchies, 209 (and cf. «On the Place of the Mystical Theology», cited below). His other works on Dionysius, in chronological order, include: Iamblichus and the Anagogical Method in Pseudo-Dionysius' Liturgical Theology // SP 18 (1979) 543-560; The Place of the Mystical Theology in the Pseudo-Dionysian Corpus // Dionysius 4 (1980) 87-98; Biblical and Liturgical Symbols within the Pseudo-Dionysian Synthesis (Toronto, 1984); Moses as the Paradigm for the Liturgical Spirituality of Pseudo-Dionysius // SP 18.2 (1989) 275-279; The Uplifting Spirituality of Pseudo-Dionysius // Christian Spirituality. Vol. I: Origins to the Twelfth Century / Ed. B. McGinn, J. MeYendorfF, J. LeClercQ (New York, 1988) 132-151; and with J. Lamoreaux, John of Scythopolis on Apollinarian Christology and the Pseudo-Dionysius' True Identity // ChH 62.4 (1993) 469-482. 
fore insists on the $C D$ as purely a kind of «head trip», «fundamentally an epistemology», and is likewise obliged to assert — frequently, I might add, in defiance of the text - that Dionysius is simply «devoid of eschatology».28

I quite agree with Rorem's assertion of the $C D$ 's unity, but decidedly not with his assessment of it. First of all, there are the quite physical facts that a) in none of the ancient manuscripts we possess does the $M T$ precede the treatises on the hierarchies, and b) that in all of the Greek manuscripts the ordering is just as we find it in volume III of Migne's Patrologia Graeca: the $\mathrm{CH}$, $E H, D N, M T$, and finally the ten «Epistles». Second, and relatedly, there is the now established fact that the $C D$ comes down to us in this order, accompanied by the Scholia of John of Scythopolis, from within a generation or two, and perhaps even less, of the corpus' actual composition. ${ }^{29}$ Third, I have already noted above how Dionysius himself grounds his very capacity for the vision of «sacred things», by which I take him to mean both the physical sight (not allowed to catechumens) of the sacraments and the spiritual perception of the Presence which informs them, in the grace he received at the «divine birth» of baptism. This in itself would certainly seem to place the $E H$ before the $D N$ and $M T$, and therefore, fourth, it seems to me clear that we are to read the treatises, including the epistles, in precisely the order in which they have been handed down to us, beginning with the $C H$ and ending, not with the $M T$, but with the tenth «Epistle». Fifth, I maintain that doing so will reveal the $C D$ as a deliberately progressive «mystagogy», that is, as at once the explication of and the entry into the one and unique mystery, Christ. ${ }^{30}$ Before I take up the $C H$ and embark on the brief «Cooke's Tour» of the $C D$ which I propose for the remainder of this essay, however, I would like first, and in disobedience to my injunction just now, to begin at the end of $C D$, at the brief «Epistle» which is addressed to none other that St. John the Divine, the author for Dionysius, at least — of both the Fourth Gospel and, as the address of the epistle indicates («To John at Patmos»), of the Apocalypse. I do so because I believe that, read correctly, this little piece reveals a great deal about Dionysius' purposes in writing, at once something of his context and of those who served as both his addressees and his targets.

${ }^{28}$ Rorem, Pseudo-Dionysius: A Commentary... 122.

${ }^{29}$ See SuchlA, Eine Redaktion der griechischen Corpus Dionysiacum...; and on the proximity of John of Scythopolis' scholia to the first appearances of the CD, Rorem, Lamoreaux, John of Scythopolis and the Dionysian Corpus: Annotating the Areopagite... 22-39.

30 Thus the choice of title for my own book, Et introibo ad altare dei... The phrase, taken from the psalms, was prescribed in the old Tridentine missal for the priest, standing at the foot of the altar steps, to begin the Mass. I was pleased by the notes of priesthood, ascent (up the steps), and entry (to the altar) into the mystery of Christ's presence (the Eucharist), together with the OT Temple cultus presumed by the psalm itself (see below and nn. 34-35). 


\section{Epistle $X$, «To the Apostle John at Patmos», as an Introduction to the Corpus Dionysiacum: A Response to Apocalyptic Literature and Visionary Practices Directed to a Monastic Audience}

It is surely curious that a writer «devoid of eschatology» should address his concluding remarks to the author of the one and only full-blooded apocalypse to find its way into the NT canon, and do so, moreover, against the background of a Syrian Church which did not accept this book as canonical until very late, indeed. Neither is this the first time Dionysius has mentioned the author of the Apocalypse. In the course of his description of the «Liturgy of the Word» in EH 3, he concludes his list of the books of scripture read in the Church with a reference to «the hidden and mystical vision of that inspired man who was the most beloved of the disciples», and then to «his transcendent theology concerning Jesus», which I take to be references, respectively, to the Apocalypse and to the Fourth Gospel. ${ }^{31}$ More remarkably still, he asserts at the beginning of Ep X that John is especially dear to him «more so than for the many», he says — and then again, toward the end, that he is «at present engaged in remembering and renewing the truth of your theology». ${ }^{32}$ What, it may fairly be asked, does this writer, whom many see as the most rarified and abstract in all of patristic literature, see in the wild and profuse imagery of the Apocalypse? The attractiveness of the high Christology of the Fourth Gospel, together with the latter's stress on the divine indwelling, is easily comprehensible, but the Apocalypse - with its candlesticks and thrones and seals and cups and descending cubical city 1500 miles on a side decorated with precious stones, furnished with flora (the «trees of life»), fauna (the Lamb and «the four living creatures» of the throne), and waterworks (the «river of life») — what can this strange book mean to the advocate par excellence of negative theology, of the denial of even the most exalted ideas to the hidden divinity, let alone the lushly tangible iconography of the Seer of Patmos?

The answer, I think, lies in three elements, two of which are contained or at least suggested in the text itself of the epistle, while the third, though not stated, is, I believe, assumed. The first comes early in the epistle: «Truly», Dionysius writes, «visible things [ta horata] are the manifest images [or icons] of the invisible». This is an allusion to R 1.20 , which Dionysius has referred to twice before, once in $D N 4$ with reference to «light» as a worthy image of God, and once in Epistle 9 to «fire» in the same context. ${ }^{33}$ Light and fire are,

${ }^{31}$ EH 3.3.4, 429D (83:21-23).

${ }^{32}$ Epistle X, 1117A and 1120A (208:4-5 and 209:12).

${ }^{33}$ Ibid. 1117B (208:9-10); cf. DN 4.4, 700C (149:7-8); and Epistle IX.2, 1108B (199:15-200:1). 
indeed, constantly present throughout the $C D$. Much more than the famous «darkness» - about which more anon — it is fire and especially light which are associated throughout the corpus with the visio dei.

This is so in turn, I think, because of that unspoken element I just mentioned. The Apocalypse of John, as with the majority of apocalypses characteristic of the intertestamental and early Christian eras, turns around a vision of the divine throne and the heavenly court, imagery which itself derives from the post- and even pre-exilic cultus of the Jerusalem Temple. ${ }^{34}$ John's cubical New Jerusalem, for example, finds its ancestry in the eschatological Jerusalem of Ezekiel 40-48, while the latter in its turn takes from the cubical dimensions of the inner sanctuary of Solomon's temple (cf. I K 7). It is at least arguable that John himself is aware of this - for want of a better word - liturgical aspect. He has his vision, after all, «on the Lord's day», the day of the Eucharist, while his portrait of the reconciliation and ultimate identity between the heavenly throne and the world to come he may quite possibly have understood as already anticipated in the worship of the local church. The brilliant and fiery Glory of God, the kevod YHWH of the Hebrew and doxa tou kyriou of the Greek, surrounded by the dark cloud, is the center of the great theophany on Sinai, and likewise at the literal heart of the Temple, as in I K 8; Is 6; Ezk 1; 9 11; 43, and in many of the Psalms. ${ }^{35}$ It is also therefore the subject of the throne visions of Dan 7, of 1 and 2 Enoch, of Rev 4-5 and 21-22, and, just for example, of the early Christian apocalypse, The Ascension of Isaiah. ${ }^{36} \mathrm{I}$ be-

${ }^{34}$ See, for example, C. Rowland, The Visions of God in Apocalyptic Literature // JSJ 10.2 (1979) 137-154; and at greater length, IDEM, The Open Heaven: A Study of Apocalyptic in Judaism and Early Christianity (New York, 1982) Esp. 78-93 and 193-248; and M. Himmelfard, Ascent to Heaven in Jewish and Christian Apocalypses (OxfordNew York, 1993) Esp. 9-46. On the «Glory of God» in the cult tradition of, particularly, the «Priestly» strain of the Penteteuch, see T. D. N. Mettinger, The Dethronement of Sabaoth: Studies in the Shem and Kabod Theologies (Lund, 1982) Esp. 80-123.

${ }^{35}$ On the importance of the book of Ezekiel for later apocalyptic visions of God and the heavenly temple, see again Himmelfarb, Ascent to Heaven... 9-28; together with J. D. LeVEnson, specifically on Ezekiel 40-48 in: Theology of the Program of Restoration of Ezekiel 40-48 (Missoula, 1976); and more broadly on the Temple, in The Jerusalem Temple in Devotional and Visionary Experience // Jewish Spirituality / Ed. A. GREEN. Vol. I: From the Bible to the Middle Ages (New York, 1988) 32-62. For a reading of the book of Revelation as fundamentally liturgical, see P. PRIGENT, Apocalypse et Liturgie (Neuchatel-Paris, 1964). On the «Glory» and visio dei in the Psalms, see M. S. SMITH, Seeing God in the Psalms: The Background to the Beatific Vision in the Bible // CBQ 50 (1988) 171-183; and, more broadly, including Isa 6, Ezk 1, and the theophanies of Exodus: J. M. VINCENT, Aspekte der Begegnung mit Gott im alten Testament: Die Erfahrung der göttlichen Gegenwart im Schauen Gottes // RB 103 (1996) 5-39.

${ }^{36}$ On the Ascension of Isaiah, see A. ACERBI, L'Ascensione di Isaia: Christologia e profetismo in Siria nei primi decenni del II secolo (Milan, 1989) Esp. 50-59 and 138-148. For a translation of the text, see OTP. Vol. 2. 164-176. 
lieve that it is no accident that the biblical texts Dionysius discusses throughout his corpus are predominantly, not to say overwhelmingly, associated with these throne visions and related theophanies. This leads me to what I take him to mean when he says he is «carrying on» John's work. He understands himself, in sum, to be linking the liturgical and Glory imagery of the Apocalypse to the interiority of the Fourth Gospel. Put another way, and to anticipate my argument later on in this essay, for Dionysius the Glory of God, the heavenly fire, and especially the divine light, is present in Christ, Who in turn appears on the altar of the consecrated eucharistic elements and in the heart or intellect - of the baptized Christian.

If we allow Dionysius this background and purpose, and I shall be providing further evidence for them along the way, then we must ask why he believes it necessary to «renew» the Apostle's teaching. I think that we have an important clue in my third element, a passage which comes from close to the middle of Epistle X:

We also see others who are, here and now, already $[e d e]$ with God, since they are lovers of truth and withdraw [anachorousi] from the passion for material things. They depart with complete freedom from every evil, and with divine love [eros] for every good thing, they love [agaposi] peace and holiness. They abandon this present life by living in a way [empoliteumenoi] which is of the [life] to come, like angels in the midst of [other] men, with total dispassion [apatheia], with invocation of the divine name, and with sanctity [hagioteti] and everything else that is good. ${ }^{37}$

Who are these angels among men? Two key terms, withdrawl (anachoreo) and abandonment (apoche), should immediately alert us to the fact that Dionysius is talking about monks. Similarly, the verb, politeuomai, here meaning «to live a [disciplined] way of life», together with the nouns, apatheia or dispassion, eros, and the latter's effective equation with agape, both meaning love here, place this passage - as well as other, lengthier ones in the $C D$ in a long prior line of patristic thought to do with asceticism and mysticism, one which runs from Clement and Origen in Alexandria through Gregory of Nyssa in Cappadocia to the great Desert Father and mystic, Evagrius of Pontus. The term sanctity, hagiotes, I would take to be Dionysius' Greek rendering of the Syriac word, qaddishuta, a terminus technicus in the Syrian Church for consecrated celibacy. ${ }^{38}$ Finally, the constant «invocation of the divine

\footnotetext{
${ }^{37}$ Epistle X, 1117B (208:12-209:4).

${ }^{38}$ On early Syriac technical terms for consecrated celibacy, including qaddishuta, see S. GRIFFITH, Asceticism in the Church of Syria: The Hermeneutics of Early Syrian Monasticism // Asceticism / Ed. V. L. Wimbush, R. Valantasis (Oxford-New York, 1995) 220-245. For qaddishuta in relation to the asceticism of Qumran and the latter's possible relevance for early Christian ascetical terminology in Syriac, see A. GuILLAUMONT, À propos du célibat des Esséniens // IDEM, Aux origines du monachisme
} 
name» is tantalyzingly reminiscent of later Byzantine hesychasm, or at least of the preoccupation with I Thess $4: 17$, «pray unceasingly», which we find throughout early monastic literature. ${ }^{39}$

It is the connection with Syria, in particular with Syrian Christian asceticism, which I believe is virtually the royal key to unlocking the mystery which the $C D$ has posed for its modern interpreters. One reason, to be sure, that no one has noticed this is that no one to date has thought to look there, with a few partial exceptions. ${ }^{40}$ The first puzzle this connection explains is why Dionysius, given his first century pseudonym, should speak of «monks» at all, and even make the seemingly ludicrous claim that the title itself, monachos, had originally been given them by the Apostles. ${ }^{41}$ The anachronism fades, however, when we take into account a NT apocryphon which is also a document of Syrian provenance, the second century Gospel of Thomas, which we know continued to read by Syrian monks throughout the fourth century AD. In Thomas, it is the Lord Jesus no less Who speaks of «solitaries», monachoi, or, in the likely Syriac original, of ihidaye (from the Syriac had, «one»). ${ }^{42}$

chrétien (Bellefontaine, 1979) 13-23. On monasticism as «the angelic life», see P. Suso FRANK, Angelikos Bios: Begriffsanalytische und Begriffsgeschictliche Untersuchung zum «Engelgleichen Leben» im frühen Mönchtum (Münster, 1964). The latter, however, seems quite without any awareness of the fact that joining the angelic priesthood was already extant in Jewish apocalyptic literature. See thus, again, HimmeLFARB, Ascent to Heaven... 29-46.

${ }^{39}$ See D. Burton-Christie, The Word in the Desert: Scripture and the Quest for Holiness in Early Christian Monasticism (Oxford-New York, 1993) Esp. 107-133 for constant «rumination» and «repetition» of selected scriptures; and specifically on the «invocation of the name [of Jesus]» in early monasticism, A. Guillaumont, Une inscription Copte sur la prière de Jésus // OCP 8 (1977) 187-203 (rep. in Aux origines... 310-325). Repetition of the divine name(s) as means to ascent to heaven appears as early as apocalyptic literature, e.g., Apocalypse of Abraham 17-18, on which see I. Gruenwald, Apocalyptic and Merkabah Mysticism (Leiden-Köln, 1980) 29 72, esp. 56-57.

${ }^{40}$ On the Syrian connection, see most notably W. Strothmann, Das Sakrament der Myron-Weihe in der Schrift De Ecclesiastica Hierarchia des Pseudo-Dionysius in syrischen Übersetzung und Kommentaren (Wiesbaden, 1978). See also Louth, Denys the Areopagite... 63-64, 69-70, and 78-98; Golitzin, Et introibo ad altare dei... 354-392; together with the scholars noted below, n. 42.

${ }^{41}$ EH 6.1.3, 532D-533A (116:15-16): «Whence our divine leaders reckoned them worthy of sacred names, some calling them 'servitors' [or «ministers», therapeutae], and others 'monks' [monachoi]...» Note that John of Scythopolis' Scholia pick up on the use of the word, therapeutae, for Jewish ascetics in the first-century work, de vita contemplativa, by Philo Judaeus (see $P G$ 4. 528A-529B), but that John is conspicuously silent about trying to supply first-century credentials for monachos, apparently unaware of the Syrian traditions discussed below and nn. 42-44.

${ }^{42}$ «Jesus said, "Many are standing at the door, but it is the solitary [monachos] who will enter the bridal chamber"», Gospel of Thomas 75 (see also logia 16 and 49), 
Later on in the fourth century, in the Demonstrations of Aphrahat of Persia and the Hymns of St. Ephrem Syrus, we meet bands of these ihidaye, the «sons of the covenant» (b'nai qeiama), whose relation to the local church precisely matches the Dionysian sketch of the monastic order presented in EH 6 and Epistle VIII. ${ }^{43}$ These Syrian ascetics are neither grouped in separate communities, in the style of Egypt's Pachomius, nor living away from the towns like the semi-anchorites of Scete or the hermits of Anthony's type. Both Aphrahat's ihidaye and Dionysius' monks live in the larger community, take part in and are assigned a special place at the liturgical assembly of the local church, receive their tonsure from the ordained clergy (unknown in Greek monastic literature prior to Dionysius) in a way that is connected with their baptism, and - in Dionysius' case most emphatically — are subject to the direction of the local bishop. ${ }^{44}$

There is no question about the emphatic quality of Dionysius' insistence on this subordination. He devotes time to it in his description of the monks in EH 6 and, at much greater length, in his eighth epistle. ${ }^{45}$ The addressee of the

tr. T. O. Lambdin, in The Nag Hammadi Library / Ed. J. M. Robinson (San Francisco, 1988) 134. On the presence of Thomas in two fourth-century, Syrian ascetical authors, see A. BAKER, The Gospel of Thomas and the Syriac Liber Graduum // NTS 12 (1965) 49-55; IDEM, Pseudo-Macarius and the Gospel of Thomas // VC 18 (1964) 214-225; and G. Quispel, The Syrian Thomas and the Syrian Macarius // VC 18 (1964) 226-235. On the relation, perhaps, of origin between the Syriac word, ihidaya, and the Greek term, monachos, see esp. F.-E. Morard, Monachos, Moine. Histoire du terme grecque jusqu' au IV ${ }^{\mathrm{e}}$ siècle // Zeitschrift für Philosophie und Theologie 20 (1973) 332-411, here 362-377. Note also her references to Dionysius in 335-336 and 405-406, and cf. M. HARL, À propos du Logia de Jésus: le sens du mot monachos // REG 73 (1960) 464-474 (here 473-474); and A. Guillaumont, Monachisme et éthique Judéo-chrétienne // Aux origines du monachisme... 47-66 (here 58), who also relate this archaic use of the term, «monk», in the Gospel of Thomas specifically to Dionysius.

${ }^{43}$ See Golitzin, Et introiboad altare dei... 354-359.

${ }^{44}$ On Dionysius as the first to assign monastic tonsure to priestly activity, thus placing it under the authority of the hierarchy, see K. Holl, Enthusiasmus und Bussgewalt beim griechischen Mönchtum: eine Studie zum Symeon dem neuen Theologen (Leipzig, 1898) 205-207. This is correct, so far as I know, with respect to Greek Christian literature, but simply wrong if applied to early Christian writers in Syriac. On the very ancient linkage in Syriac-speaking Christianity between ascetical and baptismal vows, and thus for dedication to sacred «singleness» (ihidayuta) as occurring in a decidedly ecclesiastical and liturgical context, see R. MurRAY, An Exhortation to Candidates for Ascetical Vows at Baptism in the Ancient Syrian Church // NTS 21 (1974) 59-80, perhaps esp. 77-80, and note thus Dionysius' explicit parallelism between Baptism and monastic tonsure in EH 6.3.4, 536B (118:12-15).

${ }^{45}$ EH 6.3.1, 533C (117:19-22); and esp. Epistle 8 in its entirety, 1084B-1100D (171-192). See also the one article I know of that is devoted to the Dionysian monk: 
latter is a certain monk Demophilus, whose name I take to mean something like «beloved by the mob». Demophilus has transgressed the hierarchical order, taxis, by breaking up the confession of a great sinner. He has beaten the sinner up and chased the confessing priest out of the sanctuary, where he now stands guard over the «holy things», presumably the reserved sacrament, in order to prevent their profanation a second time. ${ }^{46}$ Dionysius uses this scenario to expand at length on the virtues of meekness (praotes), mercy, and love, which in a very traditional way (reminiscent, in fact, of Evagrius) he understands as the prerequisites for the visio dei. Moses, David, and Christ Himself are the exemplars, over against Demonphilus' appeal to Elijah. ${ }^{47} \mathrm{He}$ goes on, secondly, to the necessity of maintaining the order (taxis) given by God. Monks have no authority to enter the altar area, which is here apparently separated off from the nave by a wall and curtain, and even less either to lay hands on the «holy things» or to correct the ordained clergy, even if the latter are in the wrong. This transgression of hierarchy, and thereby of the three great virtues just cited, has come about because Demophilus' own, inner hierarchy is itself out of alignment. The latter is instead «to give due place within himself to reason, anger, and to desire». This, Dionysius continues, is «the proper inner order [taxis]» without which no one can hope to rule himself, let alone others. ${ }^{48}$

R. RoQuEs, Éléments pour une théologie de l'état monastique chez Denys l'Aréopagite // Théologie de la vie monastique (Paris, 1961) 283-314, esp. 297-304 on relations between monks and clergy. For all its general excellence, Roques' article is still primarily concerned to relate Dionysius' treatment of the monk's «singleness» to Neoplatonic themes, and in consequence it misses entirely important echoes of prior Christian traditions.

${ }^{46}$ Epistle 8.1, 1088BC (175:4-13).

${ }^{47}$ Ibid. 1, 1084B-1088B (171:3-175:4); and 5-6, 1096C-1100C (186:8-192). On the importance of meekness (praotes), mercy (eleos), and love (agape) in Evagrius Ponticus ( $†$ 399), perhaps the most important architect of Eastern Christian spiritual theory, see G. Bunge, Geistliche Vaterschaft: Christliche Gnosis bei Evagrios Pontikos (Regensburg, 1988) 42-44, and IDEM, Palladiana II: La version copte de l'Histoire Lausiaque // StMon 33 (1991) 117-118. The latter is an account of a heavenly ascent Evagrius experiences, and the counsel he receives from a divine voice quite matches the advice Bishop Carpus gets from Christ in the story of the bishop's throne vision which concludes Dionysius' epistle, 1100A-C (190:5-192): God wants «meekness and mercy».

${ }^{48}$ See Epistle 8.1, 1088C (176:3) on Demophilus overturning the «divinely-given taxis» of the Church's hierarchy; and 3, 1093A (186:7-8) for his having wronged his own, inner taxis. On taxis in prior monastic literature as employed for the innerordering of the soul, see G. Gould, The Desert Fathers on Monastic Community (Oxford, 1993) 151-152. Behind both uses of the word here in Dionysius, I would see the notion of the divine «pattern» of worship which I discuss below. Note the use of OT tabernacle and temple examples - Uzziah (2 Chr. 26), the entry of the High 
Here we arrive at a second and even a third key to the $C D$. The second is the coördination between inner and outer. Implied here, as we shall see when we turn to the opening of the $\mathrm{CH}$, is the thought that the visible pattern (a term to which I shall return) of Church order - by which Dionysius means primarily the Church as we see it at worship, with its sacraments and its ordered sequence of bishops, priests, deacons, monks, laity, and catechumens, stretching from the inner sanctuary to the church porch — is a divinely-given image or icon of the order which is properly to obtain within the soul. The third key lies in Demophilus' very assumption of authority, together with the suggestion of popular approval which his name seems to imply. Now, examples of monastic zealotry are legion in the Christian East, both then and now, but I think we must look a little deeper. What was the source for the authority which this and other monastic zealots claimed? What did they think gave them the mandate to overrule ordained clergy?

This claim to authority derived from the popular belief, universal throughout the East and especially concentrated in Syria, that the monks were the successors of the seers and prophets of old. ${ }^{49}$ More than the local priest, more even than the bishop, who may have been perceived fairly often (and with occasional justice) as less a holy man than a politician, it was the monk who was the Spirit-bearer, pneumatophore, the link in his own person between this world and the one to come. In Syria, particularly, this was a very old tradition. Quite possibly, it lies behind the early second century, Christian apocalypse I cited above, The Ascension of Isaiah.$^{50}$ Likewise, as very recent scholarship has sought to demonstrate, the monachoi in the Gospel of Thomas may have represented precisely the same ascetic and visionary currents as run throughout the assorted Apocryphal Acts of the Apostles which were popular reading in the East (and West) in the Early Church, and which retained their popularity well into the fourth and fifth centuries, and even beyond. ${ }^{51}$ The Acts of Judas Thomas continued to be regular fare in the Syrian

Priest behind the veil (Lev 16:3-4, Ex 30:10, etc.) — in 1089BC (178:1-179:10). Interestingly, in his Paradise Hymns, Ephrem Syrus uses much the same imagery for Adam's transgression; see St. Ephrem the Syrian: Hymns on Paradise / Tr. S. Brock (Crestwood, 1990) 93-96 (for Hymn 3:7-16).

${ }^{49}$ See most recently P. Escalon, Monachisme et église, le monachisme syrien du $\mathrm{IV}^{\mathrm{e}}$ au VI ${ }^{\mathrm{e}}$ siècle: un monachisme charismatique (Paris, 1999) Esp. 71-123 and, on tensions with the hierarchy, 267-394.

${ }^{50}$ See AcErbi, L'Ascensione di Isaia... 217-253, 289-290.

${ }^{51}$ On the Gospel and Acts of Thomas in the Macarian Homilies, see G. QuisPel, Makarios, das Thomasevangelium, and das Lied von der Perle (Leiden, 1967) Esp. 8-13, 37-64, and 114-118; on the Gospel's possible setting in Jewish mystical traditions of ascent and vision, see A. DeConick, Seek to See Him: Ascent and Vision Mysticism in the Gospel of Thomas (Leiden, 1996) Esp. 43-125; and for the same in the Acts of John, see J. Fossum, Partes Posteriori Dei: the Transfiguration of Jesus in 
Church into early medieval times. It is also in the late fourth century that we find, orginating once again in Syria, a monastic movement which, at least according to its accusers, preached indifference or contempt for the sacraments, and more so for the leadership of the bishops, while holding that the sole access to God was through constant prayer - hence the movement's name, «messalianism», from the Syriac, tslo', to pray. ${ }^{52}$ Lastly, at least for our purposes, these monks claimed the possibility of a vision of the Trinity which they said was accessible to their physical eyes. ${ }^{53}$ While the movement was condemned in a series of regional episcopal councils beginning in Antioch in the 390's and culminating in the Ecumenical Council of Ephesus in 431 , it seems to have continued to exist in the land of its origins, Syria, well into the sixth century, which is to say, into the era of the $C D$ itself. ${ }^{54}$

I hope it is clear by now why I have taken so much time over one brief epistle. Dionysius had a problem. He was confronted, as I read him, by a tradition of ancient provenance which, in its extreme form, threatened the Church of the sacraments and bishops. Here, I think, is one very good reason, perhaps even the reason, for his adoption of a sub-apostolic pseudonym. $\mathrm{He}$ wished, simply, to answer appeals to ancient tradition with a countervailing antiquity. Another reason, surely, lies in his appeal to philosophical culture in the face of ascetics and their supporters who had no use, in Ephrem Syrus' words, for «the poison of the Greeks». Dionysius thus sets out to write his very own, New Testament pseudepigraphon, precisely in reply to other pseudepigrapha and apocrypha such as those mentioned above. He is «fighting fire with fire», and his choice of pseudonym fits neatly into his intentions: as the philosopher-disciple of St. Paul, he at once invokes the authority of the Apostle, and sustains the legitimacy of deploying the wisdom of the pagans. ${ }^{55}$

the Acts of John // IDEM, The Image of the Invisible God: Essays on the Influence of Jewish Mysticism on Early Christology (Freiburg-Göttingen, 1996) 95-108.

${ }^{52}$ On the Messalians, see esp. C. STEWART, «Working the Earth of the Heart»: The Messalian Controversy in History, Texts, and Language to A.D. 431 (Oxford, 1991); and K. Fitschen, Messalianismus und Antimessalianismus: Ein Beispiel ostkirchlicher Ketzergeschichte (Göttingen, 1998).

${ }^{53}$ For citation of the texts containing these claims, and commentary on them, see Fitschen, Messalianismus... 202-205 and 228-209.

${ }^{54}$ On the durability of the sect in Syria, see again Fitschen, Messalianismus... 286-310.

${ }^{55}$ Dionysius' pseudonymity provides a great impetus for the «hermeneutic of suspicion» practiced by his modern interpreters. The imposture must be hiding something dubious. I do not agree that the matter of pseudonymity should of itself justify this suspicion. See with regard to the philosophical culture of the day, B. D. LARSON, Jamblique de Chalcis, exégète et philosophe (Aarhus, 1972) 157, on Iamblichus' choice of a pseudonym for his de mysteriis aegypti: «Derrière la pseudonymie dans la littérature philosophique se prouve justement la conception que ce qui est décisif, 
It was also in the philosophical culture of the era, specifically in the late Neoplatonism of Iamblichus and Proclus, that he doubtless saw the potential for a reasoned balance and harmony between the subjective experience of ascetic seers, whose capacity for vision I think it clear that he affirmed (recall the «hear and now already with God» of Epistle X above), and the objective, visible liturgy of the Church through which God's presence in Christ is mediated to us. The key here lay in late Neoplatonism's denial of the soul's inherent capacity to ascend - or return - to the One. The latter doctrine had been held by the earlier philosopher and mystic, Plotinus, who also, as Porphyry his biographer tells us, had had in consequence no particular use for the rites of the temples and cults. In contrast, Iamblichus and Proclus believed that it was only through the «ineffable rites» handed down from antiquity that the inherent «weakness of the soul» could be bolstered sufficiently to participate in the divine realm. ${ }^{56}$ Now, Neoplatonist theurgy was in practice worlds away

c'est pas qui a dit ceci ou cela, mais au contraire, ce qui est» (emphasis added), i.e., it served to highlight the content rather than the author. On the pseudonymity of scriptural works and of apocryphal literature, see the essays edited by N. BROX, Pseudepigraphie in der heidnischen und jüdisch-christlichen Antike (Darmstadt, 1977), and by K. von FriTz, Pseudepigrapha I: Pseudopythagorica, lettres de Platon, littérature pseudépigraphique juive (Geneva, 1971). My own impression, suggested just above, is that Dionysius deliberately takes over the esoteric language and air of an adept ccommunicating privileged data to a chosen disciple, «Timothy» (intended to recall the addressee of the Pastoral Epistles), in order to «de-gauss», as it were, the apparatus and appeal of the apocryphal and esoteric works circulating among Christian monks of the area. His «secrecy» is in fact a pose. He intends his work to be read by many. It is public, and the esoterica he espouses in, for example, the $D N$ turn out in sum to be the «names» of Christian or, more precisely, of scriptural theology. This is the point of his insistence in $D N 1$ on Scripture as the exclusive source of the names he will discuss and, in EH 1, on Scripture as the ousia of «our hierarchy». It is quite reminiscent of St. Paul: «Nothing beyond what is written!» (I Cor 4:6, and cf. below and n. 146). Thus we have the pseudonymic effect that he wishes to obtain: the philosopher-disciple of St. Paul, initiated into the esoterica of the latter's mystical experiences (e.g., II Cor 12, and cf. n. 146 again), writes down his revelations, and we are led to discover in turn that the latter are nothing other than the common faith of the Great Church, sacramentally based, theologically orthodox. Like Irenaeus, therefore, for Dionysius there really is no esoteric revelation. All is public and open. The $C D$, among other things, is in substance an anti-esoteric work, and this message is conveyed all the more forcefully by the device of the pseudonym. I might note as well that Dionysius' modesty is too seldom pointed out. He was, after all, much more successful than Iamblichus in hiding his personal identity, doing so in order, precisely, to accentuate his message.

${ }^{56}$ See Porphyry's Vita Plotini 10, Loeb ed., tr. A. H. Armstrong, 34-35. On late Neoplatonist denial of human autonomy, see J. M. Rist, Pseudo-Dionysius, Neoplatonism, and the Weakness of the Soul // From Athens to Chartres, Neoplatonism and Medieval Thought / Ed. H. J. Westra (Leiden-New York, 1992) 135-161; and on 
from Christian liturgy. Dionysius clearly had no interest whatever in its sacred stones, crystals, unpronounceable names, seances, ectoplasm, and moving statues. In the notion, however, of a traditional and ancient worship which claimed to communicate a saving knowledge and communion, and which could moreover demonstrate that it had been received from a divine revelation vastly better documented and more consistent than Proclus' sad appeal to the spurious antiquity of the Chaldaean Oracles,${ }^{57}$ I think Dionysius must have seen not only the possibility of a missionary appeal to the pagans (which is the usual account one gets from sympathetic scholars), but, and even more importantly, a way of reconciling the occasionally clashing claims of bishops and monks, of liturgy and mysticism. Even here, though, where he is apparently very «Neoplatonist», he will in fact also be drawing on the thought of Syrian Christian ascetics who had lived over a century before him.

\section{The Celestial Hierarchy: \\ Coordination between Heaven, the Liturgy, and the Soul - a Theme from the Ascetical Literature of Early Syrian Christianity}

This brings us at last to my promised «Cooke's Tour», and so to the opening chapter of the $\mathrm{CH}$. The latter begins by quoting Jas 1.17: «Every perfect gift is from above coming down to us from the Father of lights». We therefore begin with light and its procession to us from God the Father who seeks to «gather us» back to Himself. ${ }^{58}$ Let me pause here to note the presence of this word, synagogos, «gatherer», applied to the Father and, as we shall see, its echo of the liturgy. The means whereby the Father gathers us to Himself, Dionysius then tells us, is «Jesus, the light of the Father, "the true light enlightening every man coming into the world", "through Whom we have obtained access [prosagoge] to the Father" ». ${ }^{59}$ The combination here of the Fourth Gospel and of St. Paul is worth noting in itself, but I should like particularly to underline the word, «access», prosagoge. It is in Christ, for Dionysius, that we discover our unique entry into the presence of divinity. The same word will appear again in a key text from the $E H$, and will be presumed when we come to the $M T$ and the first five epistles concluding the corpus.

Iamblichus and theurgy in particular, G. SHAw, Theurgy and the Soul: The Neoplatonism of Iamblichus (Penn State, 1995) Esp. 237 ff. For older, but still useful considerations of theurgy, see E. R. DoDDs, Theurgy and its Relation to Neoplatonism // JRS 37 (1947) 55-69; and A.-J. Festugière, Proclus et la religion traditionelle // Mélanges Piganiol (Paris, 1966) 3:1581-1590.

${ }^{57}$ See H. LEwY, The Chaldean Oracles and Theurgy: Mysticism, Magic, and Platonism in the Later Roman Empire (Paris, new ed., 1978).

${ }^{58}$ CH 1.1, 120B-121A (7:3-8); synagogou on 11. 6-7.

${ }^{59} \mathrm{CH} 1.2,121 \mathrm{~A}(7: 9-11)$. 
In the following paragraph, $\mathrm{CH} 1.3$, we arrive at the manner and means of that access which Christ has given us. This is arguably the most important passage in the entire $C D$ :

It would not be possible for the human intellect [nous] to be ordered with that immaterial imitation of the heavenly minds [i.e., the angels] unless it were to use the material guide that is proper to it, reckoning the visible beauties as reflections of the invisible splendor, the perceptible fragrances as impressions of the intelligible distributions, the material lights an icon of the immaterial gift of light, the sacred and extensive teaching [of the scriptures] [an image] of the intellect's intelligible fulfillment, the exterior ranks of the clergy [an image] of the harmonious and ordered state [hexis] [of the intellect] which is set in order tetagmenas] for divine things, and [our partaking] of the most divine Eucharist [an icon] of our participation in IC. ${ }^{60}$

Dionysius is obviously talking about the liturgy, with its candles, incense, scripture readings, orders of clergy, and sacraments. The whole is a symbol, which for him means always a kind of incarnation, a 'real presence' of God and heaven coming to us in and through the material forms and objects bread and wine, oil and water - which we have received from the teachings of Christ and the traditions of the Apostles. This symbol which is the liturgy unites three different levels: the visible and material elements of our worship, the invisible and spiritual (or «intelligible», noetos) world of the angelic liturgy about the throne of God, and the inner world of the believer's soul or intellect (nous). The first two together, that is, the Church's worship as a reflection of and participation in the worship of heaven, is a very old idea, perhaps even, as I noted above, reflected in the Apocalypse of John. ${ }^{61}$ It is in the third level, in the coördination between the interior hierarchy of the soul and the liturgy, that Dionysius offers us his apparently «novel» contribution.

My reasons for the inverted commas around «novel» will appear in a moment. For now, I should like to stress that this coördination between the «inner» and the «outer» hierarchies of the soul and Church appears throughout the treatises on the hierarchies. For example, two chapters later, in $\mathrm{CH} 3$, Dionysius gives us his definition of hierarchy as

«...a sacred order [taxis], knowledge [episteme], and activity [energeia] assimilated so far as possible to the form of God [to theoeides] and leading up in due proportion to the illuminations given it by God». ${ }^{62}$

Its purpose (skopos), he continues, is to make its members «images [agalmata] of God... clear and spotless mirrors reflecting the primordial light», ${ }^{63}$

\footnotetext{
${ }^{60} \mathrm{CH} 1.3,121 \mathrm{C}-124 \mathrm{~A}(8: 19-9: 6)$.

${ }^{61}$ See above, nn. 34-35.

${ }^{62}$ CH 3.1, 164D (17:3-5).

${ }^{63}$ CH 3.2, 165A (17:10-18:4).
} 
which is to say that «hierarchy» refers both to the collective, that is, in our case to the worshipping Church, and to the individual Christian. Both, with the latter arriving at it in and through the former, are called to be the imago $d e i$, and thus to become vessels of the divine light. Recall in my citation of CH 1.3 above that he called the ranks (diakosmeseis) of the clergy an image or icon of that condition or state, hexis (like the Latin habitus), of the inner man which is open to - literally, «set in order for» - the reception of divine things. Now remember our examination above of the problem posed in Epistle VIII by the monk, Demophilus. The latter disrupted the sacred order, taxis, of the Church, which Dionysius consistently refers to as «our hierarchy» (the collective), because the inner order, taxis, of his soul (the individual) was already out of order. Demophilus had, in short, refused to allow the shape or pattern of the liturgy precisely to shape or form his inner man, and had thus, as Epistle VIII also makes clear, rendered himself opaque to the vision of God. The liturgy is therefore for Dionysius not merely a sign - a «symbol» in the weak, modern sense - but a shaping force without which no one can attain to the encounter with God within. It is in this sense that we are to understand Dionysius' insistence in the $\mathrm{CH}$ and elsewhere on the «hierarchic principle», for example in $\mathrm{CH}$ 8: «that beings [here, angels] of the second rank receive enlightenment from God through the beings of the first rank», ${ }^{64}$ a principle which, applied to «our hierarchy», means the authority of the clergy. Two chapters later, however, we find the same principle applied to the inner life: «Every being endowed with intelligence...has its own set of primary, middle, and lower orders and powers». ${ }^{65}$ Likewise, and a final example, in $E H 3$, which is devoted to the Eucharist, Dionysius refers to this sacrament as the synaxis, from synago, to gather together (and recall in $\mathrm{CH} 1.1$ above the Father as synagogos, gatherer). At one point he applies this to the individual: the Eucharist is that sacrament which "gathers together into unity the divisions within us» ${ }^{66}$ and then, later in the chapter, to the collective, where it is the function of the Eucharist to bring us together without divisions «among ourselves». ${ }^{67}$

I could multiply examples, but these must suffice to illustrate my point: Dionysius does not believe in the autonomous human intellect. The latter is neither capable of, nor free to approach the Godhead on its own. It requires the liturgy, the community of the Church, to form it and render it capax dei. Here, to be sure, we can certainly point to a parallel in the late Neoplatonist notion of theurgy, the «ineffable» and immemorial rites which alone can afford the presence of the gods to a soul too weak by nature to ascend to them

\footnotetext{
${ }^{64} \mathrm{CH} 8.2,240 \mathrm{D}(34: 14-16)$.

${ }^{65} \mathrm{CH} 10.3,273 \mathrm{C}(40: 23-41: 2)$.

${ }^{66} \mathrm{EH} \mathrm{3.1,} \mathrm{424C} \mathrm{(79:9-12).}$

${ }^{67}$ EH 3.3.8, 437A (88:13-18).
} 
by itself. The parallel is obvious, and I freely grant that Dionysius made use of it. It may even have been what attracted him to Proclus and company in the first place. Let me add two caveats, however. There is first the certainty that Dionysius felt that he had a superior revelation and better - much better rites. The pagans were obliged to turn Plato into holy writ and to rely on the dubious and late mystagogy of the Chaldean Oracles. The Christian writer, by contrast, could and did point to the incontestably revelatory claims of Scripture, together with a liturgy that could document a pedigree going back to the Apostles, and still further to an even more distant, if transformed, ancestry in the cult of the Jerusalem Temple and, indeed, even before Solomon, to the worship of the tabernacle revealed to Moses on Sinai (Ex. 25:9 ff.) as, exactly, the divinely-given pattern of worship ${ }^{68}$ The imagery of the Old Testamental Temple, not accidentally I think, is ubiquitous throughout the $C D .{ }^{69}$

68 «In accordance with all that I show you concerning the pattern [Hebrew tabnit, LXX paradeigma] of the tabernacle and of all its furniture, so shall you make it»; Ex 25:9 (NRSV). Cf. Dionysius' discussion of the «three hierarchies» — the «legal hierarchy» (he kata nomon hierarchia), «our hierarchy» (he kath' hemas hierarchia), and the angelic hierarchy — in EH 5.1.2-4, 501B-503A (104:15-107:12). The discussion is in great part based on, and flows out of Exod. 25:9 ff., thus the explicit reference to Sinai and the tabernacle in 5.1.2, 501C (105:11-16). Throughout, the assumption behind the discussion supposes the modeling of human worship on the liturgy of heaven, less perfectly in the case of the OT cultus, more perfectly in the Christian, and cf. Heb 10:1, the distinction between «shadow», skia, and «image», eikon. That Dionysius is in accord here with ancient and contemporary traditions (esp. lively in Syria) concerning the tabernacle/temple and Christian Church, see for example N. SÉD, Les Hymnes sur le paradis de saint Ephrem et les traditions juives // Mus (1968) 455-501, here 458-465 and 476-477. For the OT and later Jewish thought, see again LEVENSON, The Jerusalem Temple in Devotional and Visionary Experience...; J. D. LEVEnson, Sinai and Zion: An Entry into the Jewish Bible (San Francisco, 1985) Esp. 89-184; and R. PatAi, Man and Temple in Ancient Jewish Myth and Ritual (New York, 1967²).

${ }^{69}$ See $\mathrm{CH} 1.3,124 \mathrm{~A}$ (our hierarchy assimlated to the angelic priesthood); 4.3, 180C (angels as initiators); 7.2, 208A (highest angels as «gates», prothyroi, to the sanctuary of divinity); 7.4, 212B (echoes of Ezk 3:12 and Isa 6:3, also angels as the «place» of divine «rest»); 8.2, 241A-C (angels as priests, echoing Ezk 9; 10:6-8; and Zech 1:3 and 2:4); 13.4, 304C-305B (Isaiah's «initiation» into the liturgy of heaven); $15.4,333 \mathrm{AB}$ (angels with priestly vesture); EH 1.1, 372AB (Jesus established our priesthood); 4.3.5-6, 440B-D (Seraphim around Christ as priests around the bishop); 5.1.2, 501BC (see above, n. 68); 5.1.7, 508CD (clergy as icon of divine energies); DN 1.8, 597AB («visions» englightening «prophets in the holy places», echoing Ezk. 9-11, Ex 24 and 33-34, and Rev 4-5); 4.2, 696B («to reflect the light glowing in the inner sanctuary», i.e., the heavenly debir); 4.22, 724B (an angel as a «mirror... enlightening within itself... the goodness of the silence of the inner [heavenly] sanctuaries»); 5.2, 816C (Godhead's foundation «in a secret place», cf. Ps 80:8); 5.8, 821C (highest angels as again prothyroi of the Trinity); MT 1.1, 997AB (a likely echo of the darkness of the debir in the «brilliant darkness of the hidden silence»); 1.2, 1000AB 
My second caveat refers back to the inverted commas I placed around the «novelty» of Dionysius' contribution regarding the coordination of the inner and outer liturgies, and thus to my earlier remark that he was drawing upon a Syrian Christian literature that antedated him by over a century. Here I have in mind primarily three fourth-century Syrian writers, Ephrem Syrus (†373), and the anonymous authors of the Liber Graduum (Book of Steps) and the Macarian Homilies. ${ }^{70}$ The first two wrote in Syriac and the third in Greek. The last two in particular were also concerned especially with what I argued in my discussion of Epistle VIII was Dionysius' fundamental goal: the reconciliation of ascetics, especially of ascetic visionaries, to the liturgy and sacraments of the Church. These earlier Syrian writers were themselves involved with the ascetic movement — or, perhaps better, bundle of traditions — which was later to be condemned as Messalianism, and they, too, were anxious to propose a solution to the dangers which they saw that movement, with which they had much in common, posing for the life of the Great Church. ${ }^{71}$ The outlines of their solution match those of Dionysius. Indeed, the match is on occasion virtually exact, as in the following from Macarius which my citation from $\mathrm{CH} 1.3$ echoes over a century later:

(«darkness his hiding place», cf. Pss 18:11 and 80:8); 1.3, 1000CD (the «place of God» to which Moses ascends, cf. Ex 24:10); Epistle 5, 1073A-1076A (the «darkness» and «unapproachable light» in which God dwells, cf. I Tim 6:16); Epistle 8.1, 1089BC (see above, n. 48); 8.6, 1100AC (appearance of Christ on heavenly throne, «shining flame», surrounded by angels). To these I might add $\mathrm{CH} 2$, esp. 1-2 and 5, 137A-D and 145B (almost exclusively devoted to Ezk 1); the entirety of chapters 13 , 300B-308B, on Isa 6:1-6; and 15, esp. 2-5, 328C-340B (again almost exclusively devoted to Ezk 1 and 9-11); DN 9.5, 912D-913B (alluding to the OT theophanies in bodily form); and 10.2, 937B (echoing Dan 7:9 and 13). This list does not claim to be comprehensive. I am merely noting the passages which most forcibly struck me.

${ }^{70}$ For Ephrem, see the translation by Brock, Hymns on Paradise... (cited above, n. 48); and for the Liber Graduum, M. Kмоsкo's edition of the Syriac text with facing Latin translation in PS III. Macarius' homilies and letters exist in four medieval collections, three of which enjoy critical editions: Makarios/Symeon: Reden und Briefe. Die Sammlung I des Vaticanus Graecus 694 (B). 2 vols. / Ed. H. Berthold (Berlin, 1973); Die 50 geistlichen Homlien des Makarios / Ed. H. Dörries, E. KlosterMANn, M. KröGer (Berlin, 1964); and V. Desprez, Pseudo-Macaire. Oeuvres spirituelles. Vol. I: Homélies propres à la Collection III (Paris, 1980) (SC, 275). There is a handy translation of Collection II by G. MALONEY, Pseudo-Macarius: The Fifty Spiritual Homilies and the Great Letter (New York, 1992).

${ }^{71}$ For discussion, see Golitzin, Et introibo ad altare dei... 371-385. Note that for long both the Liber and, especially, Macarius were themselves confused with the Messalian heresy. For Macarius as «Messalian», see, e.g., A. Louth, The Origins of the Christian Mystical Tradition: From Plato to Denys (Oxford, 1981) 113-125. It is the great merit of STEWART, «Working the Earth of the Heart»... and FitscheN, Messalianismus... (both cited above, n. 52), to have cleared up this confusion. 
Because visible things are the type and shadow of hidden ones, and the visible temple [a type] of the Temple of the heart, and the priest [a type] of the true priest of the grace of Christ, and all the rest of the sequence of the visible arrangement [a type] of the rational and hidden matters of the inner man, we receive the visible arrangement and administration of the Church as a pattern [hypodeigma] [of what is] at work in the soul by grace. ${ }^{72}$

Once again, we find the language of a divinely-given pattern of worship. Christ came, the same writer says a little earlier, and gave us the «icon of the Church» in order that «faithful souls might be made again and, having received transformation [metabole], be enabled to inherit everlasting life». ${ }^{73}$ The liturgy is thus not merely a sign or projection of the soul outwards, but, as in Dionysius later on, a transforming force molding the soul from within.

The Liber Graduum, whose author is confronted by certain ascetics living away «off on the Mountain» and disdaining the liturgy and sacraments, offers an exactly similar coördination between, as he puts it, the «three churches»: the heavenly church, the earthly church of sacraments and clergy, and the «little church» of the heart. It is the middle term, he insists, the earthly church, which enables the Christian «to find himself in the Church of the heart and [thence] in the Church on high». ${ }^{74}$ Finally, and apparently outside of any controversy, Ephrem Syrus' Hymns on Paradise offer a striking set of parallels between: (1) the Paradise Mountain; (2) Sinai; (3) the Jerusalem Temple; (4) the Christian Church; and (5) the human being. On the peak of the Paradise Mountain enthroned on the Tree of Life, on the summit of Sinai, within the holy of holies of the Temple, on the altar of the Church, and in the innermost chambers of the human spirit we find Christ. ${ }^{75}$ Ephrem also, on at least one occasion, refers to Christ's presence as the Shekinta, i.e., he deploys the

${ }^{72}$ Makarios/Symeon: Reden und Briefe... Homily 52.2.1 (vol. II. 140, lines 3-8). See A. Golitzin, Liturgy and Mysticism: The Experience of God in Orthodox Christianity // Pro Ecclesia 8.2 (1999) 159-186, here 176-179, for further discussion of Macarius.

${ }^{73}$ Ibid. 1.6, 139:30-140:2. The «transformation», metabole, is here a deliberate evocation of the change of the Eucharistic elements. On Macarius' frequent use of liturgical imagery and terminology for the inner condition of the soul, see Golitzin, Liturgy and Mysticism... 177-179, and at greater length: IDEM, Et introibo ad altare dei... 379-385.

${ }^{74}$ Mimra 12.2, PS III, 288:20-289:8. See also the English translation of this discourse, in S. Brock, The Syriac Fathers on Prayer and the Spiritual Life (Kalamazoo, 1987) 45-53, here 46-7. The similarity between Macarius and the Liber in their effort to coördinate the worship of heaven, the church, and the soul, was first noted by R. Murray, Symbols of Church and Kingdom: A Study of Early Syriac Tradition (Cambridge, 1975) 262-276.

75 On these parallels, see Brock's «Introduction» to the Hymns on Paradise... 46-57, esp. the chart he supplies on p. 54. 
same word (in its Syriac form) as the Shekinah of the Rabbis, who in their turn use it to mean the radiant manifestation of God, the divine Glory abiding in Israel. For Ephrem, and I think also for Dionysius, though he never uses that term, this radiance and splendor of God in Christ abides in the Church and in the Christian. ${ }^{76}$ It is the secret within the complementary sanctuaries of the Church and the heart.

There are in fact a number of fascinating echoes of St. Ephrem in the $C D$, including the former's use of another word, raza, which he employs in a way very akin to the dionysian use of symbolon, symbol, both for what we might call the symbolic discourse of Scripture, the names of God in particular, and for the sacraments themselves. ${ }^{77}$ In both writers there is a continual to and fro between the poles of hidden and revealed, God present in His «symbols» or «mysteries» and at the same time veiled by them. For our purposes, though, it is particularly Ephrem's parallels between Sinai, Church, and the soul that I should like us to bear in mind, since I think that they provide us with a key that unlocks the relationship which obtains for Dionysius between the two treatises, the $E H$ and, especially, the ascent of Moses up Sinai which begins the $M T$ and provides the setting for the latter treatise's concluding series of negations.

\section{The "Architecture» of the Church at Worship in The Ecclesiastical Hierarchy: "Bracketing" all of Christian Life}

We turn then to the $E H$, «our hierarchy», the Church. By the latter, Dionysius means essentially the Church at worship. It is composed of three triads, like the three triads of the angelic orders in the $\mathrm{CH}$, save that in our case the

${ }^{76}$ Hymns on Paradise 2.11 (Brock, 89). For the Syriac, see E. Beck (ed.), Des heiligen Ephraem des Syrers: Hymnen de Paradiso (CSCO, 174) 7, line 28. The term, šekinta, turns up with some frequency in Christian writers in Syriac. I have come across it Aphrahat (fl. 340s), Jacob of Serug († 521), and Isaac of Nineveh († ca. 690), where each time, I believe, it signals the presence of Christ. To my knowledge, however, this usage has not yet attracted any scholarly attention. For the rabbinic usage of šekinah, see A. M. GoldBERG, Untersuchungen über die Vorstellung der Shekinah in frühen rabbinischen Litteratur (Berlin, 1969); and in the targumim, D. MuÑoz-LeOn, Gloria de la Shekinta en los targumim de Penteteucho (Madrid, 1977). For its use in Jewish mystical texts, see I. CHERnus, Mysticism in Rabbinic Judaism: Studies in the History of Midrash (Berlin-New York, 1982) Esp. 74-87. On echoes of these traditions in Dionysius, see my discussion of $M T 1.3$ and Epistles 1-5 below, and, in more detail: A. Golitzin, Revisiting the 'Sudden': Epistle III in the Corpus Dionysiacum // SP XXXVII (2001) 482-491, esp. n. 3, 482-483.

${ }^{77}$ See E. BECK, Symbolum-Mysterium bei Aphraat und Ephräm // OC 42 (1958) 19-40; and R. Murray, The Theory of Symbolism in St. Ephrem's Theology // ParOr 6-7 (1975/76) 1-20. 
first triad is composed of the sacraments of baptism, eucharist, and the consecration of the sanctifying perfumed oil, the myron, used to anoint the newly baptized and to consecrate the altar. It might strike us nowadays as unusual to rank the consecration of the oil as a sacrament, but this was apparently commonly believed in the Syrian Church of the era. ${ }^{78}$ Likewise, the bottom triad of monks, baptized laity, and catechumens/penitents also might appear odd or contrived, but once more we see exactly the same sequence of three grades in Ephrem's Paradise Hymns ${ }^{79}$ In between, mediating the sacraments to the laity, we find the triad of sacred ministers - bishops, presbyters, and deacons (whom Dionysius calls hierarchs, priests, and ministers - leitourgoi) familiar to us from at least the days of another Syrian, Ignatius of Antioch $(\dagger 115)$, who is, interestingly enough, the only Church Father whom Dionysius feels free to cite by name. ${ }^{80}$ Every one of these triads is therefore traditional, though the $E H$ is the first to assemble them in precisely this sequence. One reason for this assembly, aside from the undoubted Neoplatonism of triads within triads (which has drawn most of the scholarly attention), is surely Dionysius' wish to emphasize the mediating role of the clergy, particularly with respect to the monks.

It is on the design or «architecture» of the $E H$ that I should like dwell here, while recalling the mountain imagery we saw in Ephrem and will see in the $M T$. The treatise features two primary movements, the first into the mystery of the altar and culminating in the meditation on it at the end of chapter 4 on the myron, and the second moving away from the altar as the reader is led through successive meditations on clerical ordination, accomplished within the sanctuary in chapter 5, to monastic tonsure, done in front of the sanctuary gates in chapter 6 , to the concluding chapter 7 , on Christian burial, which begins in the nave and finishes by taking us out of the church building on the way to interment. We thus enter the Church through baptism, commune at the eucharist, reflect on the altar itself, and then trace the movement of divine grace moving down from the altar in order to finish once again «outside the doors» of the Church in hope of the Resurrection. Chapters 2, on baptism, and 7, on burial, constitute a kind of «bracket» which encloses the whole of Christian life. Dionysius speaks in fact of two births and two deaths. The first birth is of course the «divine birth» of baptism where, as we saw above, we receive the «eyes of the mind» capable of perceiving divine things, and which we are given through participation in the figurative death of baptismal im-

${ }^{78}$ See esp. Strothmann, Das Sakrament der Myron-Weihe...

${ }^{79}$ See Hymns on Paradise 2.10-11, (BRock, 88-89); and, for comment on this triad, Murray, The Theory of Symbolism in St. Ephrem's Theology ... 9.

${ }^{80} \mathrm{DN}$ 4.12, 709B (157:10-11). For Ignatius' triad of clergy, see for example his letter To the Phillipians 4. 
mersion, in imitation of Christ's death and burial. The literal death of the Christian in chapter 7 looks forward to the «rebirth» [paliggenesia] of the resurrection precisely in fulfillment, as Dionysius is careful to stress, of the baptismal promise. ${ }^{81}$ Thus, while describing the sacramental rites and offices of the visible church, the $E H$ simultaneously represents, enclosed within those brackets, the Christian's existence, hope of the world to come, and possibility of communion with God in this life. Once more, in short, we find that principle of coördination between macrocosm and microcosm, outer and inner, objective and subjective, institutional and personal, which I stressed above in connection with $\mathrm{CH} 1.3$ and the latter's background in Syrian ascetical literature.

Space permits me to dwell only on one text from the $E H$, but I think it an essential one. It is the passage referred to above at the conclusion of $E H 4$. This is simultaneously the climax of the first movement, the entry or «introit» into the mystery of the Church and, if I may borrow from St. Ephrem's imagery, the summit of the ascent of the Church as the mountain of God. Given the latter image, I think this passage also has a direct relation to Dionysius' use of Mount Sinai in the MT. After describing the rite of the sacred oil's consecration, an action which takes place entirely within the veiled sanctuary (and hence, perhaps, one reason he has chosen this sacrament as the background for his concluding reflections on the movement into the mystery), Dionysius begins his contemplation, theoria, with a lengthy discussion of the saints. It is these people, he tells us, who «are the truly divine images of that infinitely divine fragrance ${ }^{82}$ which has taken up its lodging «within their minds», and, as he makes clear a few paragraphs later, that fragrance is the presence of Jesus. ${ }^{83}$ After an extended consideration of the seraphim gathered about Christ in heaven, as typified by the clergy around the bishop at the altar, and following repeated reflections on the Incarnation, he sums up his remarks on the altar and on our participation in Christ with the following:

The theurgy [by which term Dionysius always means the Incarnation] transcends the heavens and is superessential. It is the origin, essence, and perfecting power of all our divinely-worked sanctification. For if our most divine altar is Jesus, Who is [both] the divine consecration of the heavenly intelligences [i.e., the angels] [and $\mathrm{He}$ ] in Whom we, according to the saying, being at once consecrated and in mystery wholly consumed [lit. be-

${ }^{81}$ EH 2.1, 392AB (69:3 and 7) for Baptism as anagennesis and gennesis; and 7.1 and 3, 553A and 556B (120:23 and 123:15) for the paliggenesia of the Resurrection anticipated in Christian burial. Note also Dionysius' specific indication of the funeral service's appeal to, and parallel with, the «divine birth (theia gennesis) of Baptism in $7.3 .8,565 \mathrm{~A}(129: 15-22)$.

\footnotetext{
${ }^{82}$ EH 4.3.1, 473B (95:21-96:5).

${ }^{83}$ EH 4.3.4, 480A (99:8-14).
} 
come whole burnt offerings, holokautomenoi], have our access [prosagoge] [to God], let us gaze with supramundane eyes on this most divine altar, by whom all that is being perfected is perfected and sanctified, made perfect by Him Who is Himself [also] the most divine myron. ${ }^{84}$

In this passage, we find, first of all, the reference to the holy man whom Dionysius sees as typified by the sacrament; second, the coördination between heaven and earth, the liturgies around the divine throne and the Christian altar; and, third, the identification of both altars, on high and here below, with the God-man, Jesus. Thus we encounter, yet again, the harmony or mutual reflection established between not only the liturgies of heaven and earth, but as well between both the latter and, to borrow from the Liber Graduum, the «little church» of the individual Christian. I have a fourth point, too, and that lies in what I take to be the relation - indeed, perhaps even the functional identity — between the passage quoted here and Moses' entry into the divine darkness in the $M T$. We enter into God through God, and God for Dionysius here means Christ. We do so as both «consecrated and, in mystery, wholly consumed». I cannot help but see a direct relation between this holocaust on the peak of the «Mountain of the Church» (borrowing now from St. Ephrem's imagery), and the divine darkness on Sinai into which Moses plunges in the $M T$, stripped of every concept and of all human knowing. In both passages, we must be «burned up» altogether, as it were, in order to enter fully into God. Put in more pedestrian terms, I take this passage as the context, so to speak, for the apophaticism of the $M T$. It is the Church, the body of Christ, which is for Dionysius the divine milieu, the «place» of encounter with God, the topos theou, and therefore also the place for our considerations of the following treatises, the $D N$ and the $M T$. But what then of that «dazzling darkness» of divinity which we shall meet in the latter treatise? That too, as we shall see, is Christ.

${ }^{84}$ EH 4.3.12, 484D-485A (103:4-9). Cf. the description of the sanctified believer as a «holocaust» (holokautoma), offered up by Christ the High Priest and consumed by «spiritual fire», in Homily 7.2 in Collection III of the Macarian homilies: Pseudo-Macaire. Oeuvres spirituelles... 118-121, esp. 118:1-12, with lines 4 and 10 for holokautoma and holokarpoma, resp. The image is also reminiscent of secondcentury descriptions of the Christian martyr as sacrificial offering and, indeed, as a kind of sacrament making God present. See, e.g., Ignatius himself in Romans and Polycarp in the Letter of the Smyrneans. For citation and discussion of the latter texts, see Golitzin, Et introibo ad altare dei... 243-247, together with R. D. Young, In Procession before the World: Martyrdom as Public Liturgy in Early Christianity (Milwaukee, 2001) Esp. 9-24. 


\section{The Divine Names: Notes of Eschatological Anticipation and on "Spiritual Fatherhood» as Illustration of the Trinity}

The long treatise of the $D N$, which has fascinated so many generations of systematic theologians, especially the great Scholastics, will not detain us as long as it should. The first three chapters do, however, require a brief consideration.

Chapter 1 sets out the basis of discussion, beginning with an opening appeal to the apophaticism which also closes the treatise in chapter 13 and leads naturally into the MT: «God is properly known through an «unknowing» (agnosia) beyond mind and speech. ${ }^{85}$ Dionysius moves on to declare that the treatise is to be limited entirely to «what scripture has disclosed» in the «hidden depths» of the names it has given God, ${ }^{86}$ names which, as he implies elsewhere, are, we might say, sacramental in their character. ${ }^{87}$ They carry the divine presence. Section 3 of the chapter asks its readers to «lift up» their eyes to this «divine light», and continues its praise of the light in ways which, to my ear, recall key terms of Syrian Christian asceticism. The divine light of scripture is «safety for those make a stand... simplicity for those turning toward simplicity». ${ }^{88}$ The fourth section is also one of the keys to the treatise and, indeed, to the entire corpus. Dionysius begins it by recalling the Trinity, God as monad and triad, and then the Incarnation, where God «became complex» by entering «into our human nature». ${ }^{89}$ In what follows, this «complexity», the «vesture» we might say of the Incarnate God — or, in

${ }^{85}$ DN 1.1, 585D-588A (108:4, for agnostos, and 9, for agnosia «beyond reason [logos] and intellect [nous]»), and for the closing appeal to apophaticism, see 13.3, 981AB (229:15-230:5).

${ }^{86}$ DN 1.2, 588C (110:2-4), repeating what he has already said in $1.1,588 \mathrm{~A}$ (108:6-8).

${ }^{87}$ See, e.g., $D N 1.8,597 \mathrm{BC}$ (121:4-15), where Dionysius speaks of interpretation of the divine names in terms and phrases which deliberately evoke the disciplina arcana traditionally (at least from the fourth century) applied to the sacraments, e.g., «holy things are for the holy» (121:9-10), still sung today in the Orthodox Church prior to the fraction and priest's communion. Cf. also 9.1, 909B (207:8), on the divine names as theia agalmata, «divine images» or «icons», and, for discussion, GolitzIN, Et introibo ad altare dei... 70-74.

${ }^{88}$ DN 1.3, 589A-C (111:3-112:6), with esp. 589C (121:16-112:2) for the terms which remind me of the lexicon of Syrian asceticism: «those who stand» (111:16), «simplicity» and «oneness of those being unified» (112:2). The first, «standing», recalls the qeiama, «covenant», of the ascetics, but whose root is «stand» $(q w m)$, while the last two evoke the ihidaya, or «single one», the root of which is $h d$, «one». On the several resonances of qeiama and ihidaya, see again GrIFFITH, Asceticism in the Church of Syria... (above, n. 38), esp. 223-234.

${ }^{89}$ DN 1.4, 589D-592B (112:7-114:7). 
Dionysius' phrase, the «veils» of God's love for humanity (philanthropia) are specifically equated with the scripture and liturgy (= «the hierarchical traditions») which establish the possibility of our approach to the divine mystery «now», i.e., in this life. «But THEN», as he continues, in the age to come:

We shall... be filled, on the one hand, with pure contemplation of His most visible theophany, shining round us with manifest brilliance as it shone round His disciples at the divine Transfiguration, and, on the other hand, we shall [also] participate in His noetic gift of light with our intellects grown passionless and immaterial; and [finally we shall share] in the union which transcends the [created] intellect through the unknowable and blessed impulsions of [His] supra-luminary rays in a more divine imitation of the heavenly intellects because, as scripture says, «we shall be equals to the angels and sons of God, being sons of the Resurrection»..$^{90}$

Let me underline three things here: first, the explicit affirmation of three levels or aspects of the beatific vision: body, intellect (nous), and beyond the created frontiers of both the latter in union with the «supraluminary rays» of divinity. Second, we find the appeal to the Transfiguration's portrait of Christ's own transformed body. ${ }^{91}$ The entire human composite is thus to be redeemed and transfigured, which affirmation, third, is quite in accord with what we have seen elsewhere, particularly in the $E H$.

This is not, however, the end of the passage which, up to this point, has been bracketed by a now (nyn) - then (tote) construction reminiscent of St. Paul in I Cor 13.12: «now in a glass darkly, but then face to face». Dionysius also admits the real, if fleeting and partial, possibility of a glimpse of eschatological realities in this life, and here he is again in complete accord with his ascetic sources. The Liber Graduum likewise insists on the possibility of vision «in this world» (bhan alma), as do the Macarian Homilies (apo tou nyn, «right now»), and Evagrius Ponticus..$^{92}$ «As for now» (nyn de), Dionysi-

${ }^{90}$ Ibid. 592BC (114:7-115:5). On this passage, see A. Golitzin, «On the Other Hand» // SVTQ 34.4 (1990) 305-323, esp. 310-316.

${ }^{91}$ On the huge importance of the Transfiguration in Eastern Christian thought, see J. McGuckin, The Transfiguration of Christ in Scripture and in Tradition (Lewistown-Queenstown, 1986) Esp. 99-143.

${ }^{92}$ For the Liber's bhan alma, see Mimra 15.16, PS III, 373:12-13, and relatedly, «the migration» to the heavenly church «while still in this present life» in 12.2, 288:20 289:8; trans. in Brock, Syriac Fathers on Prayer... 46-47. For Macarius' apo tou nyn: see, e.g., Collection I, homilies 33.3.6 (BERTHOLD II:31, line 14); 34.1 (II:34, lines 4-5); 50.2.3 (II:127, line 1); 54.4.6 (II:157, line 12); and 58.2.5 (II:184, line 25). In the last-named, note as well Macarius' insistence on the divine and objective nature of the light which appears - not a noema, a product of the intellect, but an hypostatikon phos, «substantial light» (II:183, lines 14-15). For Evagrius, see the 
us thus continues, we use the analogies and symbols given us in the tradition, rise to the perception of the presence - the unity and simplicity, as he puts it - which informs them, and then cease the exercise of our own powers altogether in order to allow those of Another to take over, the «ray beyond being». ${ }^{93}$ This is exactly the sequence he uses later in describing the ascent of Moses in the $M T$, and to which he also returns nearly a dozen times in the $D N$. The mysteriously impelling force which takes us over in this ascent is, as he spells out at length in $D N 4,{ }^{44}$ nothing more nor less than God's own love, His eros or agape, which moved Him to create us and this world in the first place, and, in the second, to redeem His creatures in the Incarnation.

For anyone familiar with patristic literature dealing with the Trinity, particularly the thought of the great Cappadocian fathers of the fourth century, there are no surprises whatever in $D N 2$. It is straight Cappadocian triadology, together with, chiefly in its concluding section, a continuation and intensification of the essence/energy distinction which Basil the Great and Gregory of Nyssa had adumbrated over a century before Dionysius. ${ }^{95}$ Bearing in mind, however, the links between between the $C D$ and the ascetic tradition which I have sought to establish, I should also point out $D N 2.8$. The subject here is the relation of the Trinity to the process of deification, theosis, as the latter is realized in the uniquely intimate relationship obtaining between a «spiritual father» and his disciple, or «son». «Fatherhood and sonship of this kind», Dionysius writes, «are brought to perfection in a spiritual fashion... and this is the work of the divine Spirit». ${ }^{96} \mathrm{He}$ does not state that this relationship is uniquely monastic, which indeed it need not be, but there is equally no question that the mysterious bond between a Christian elder (geron) and his (or her!) disciple were highlighted in a new and peculiarly powerful way precisely in the literature of fourth century monasticism. ${ }^{97}$ Dionysius

texts assembled and analyzed by G. Bunge, Nach dem Intellekt Leben? Zum sogennanten «Intellektualismus» der evagrianischen Spiritualität // Simandron, der Wachklopfer: Gedankenschrift für Klaus Gember / Ed. W. NysSEN (Köln, 1989) 95-109; together with N. SÉD, La Shekinta et ses amis araméens // COr XX (1988) 230-242, esp. 240-242; and Golitzin, Et introibo ad altare dei... 335-338.

${ }^{93}$ DN 1.4, 592C-593A (115:6-18).

${ }^{94}$ DN 4.10-17, 705D-713D (154:7-162:5).

${ }^{95}$ See C. PERA, Denys le mystique et la theomachia // RSR 25 (1936) 5-75, esp. 36-49; Louth, Denys the Areopagite... 89-91; and Golitzin, Et introibo ad altare dei... 49-54 and 289-304.

${ }^{96}$ DN 2.8, 645BC (132:5-13).

${ }^{97}$ To scratch the surface of a large and growing bibliography: for a sensitive, if somewhat dated, analysis of the relationship between spiritual father and son in Eastern Christian ascetical literature, see I. Hausherr, Spiritual Direction in the Early Christian East / Trans. A. Gythiel (Kalamazoo, 1990) Esp. 1-98 and 123-151, together with K. T. WARE's «Forward», vii-xxxiii. See also H. J. M. Turner, St. Syme 
sees in this relationship, further, an image - arguably for him even the image - of the Trinity itself, while adding, in a phrase we should remember when coming to the negations of $M T 5$, that, as with all other images, «the Father and the Son supremely transcend all divine fatherhood [patrotes] and sonship [huiotes]». ${ }^{98}$ Let alone the physical begetting of sons, even this exalted image derived from a purely spiritual begetting is, in the last analysis, inadequate to its prototype in the divine life. I might add that I have never seen this passage connected with its obvious roots in Christian ascetical tradition in any of the scholarly literature, including — prior to this essay, at least - my own.

$D N$ chapter 3 takes up yet another theme emphasized in ascetic literature, especially in Evagrius of Pontus: prayer. ${ }^{99}$ It is prayer which constitutes the privileged path to divine encounter, the way par excellence through which we, in Dionysius' own terms, become present to God. Again, this phrasing and the marked emphasis he places on human passivity in the higher reaches of prayer places him, I think, squarely in the company of the earlier desert fathers in general and, once more, of Evagrius in particular. The passive note of the experience of God is specifically underlined earlier, in chapter 2, where Dionysius speaks of his spiritual father, Hierotheos (about whom we know nothing), «suffering» the mystery of the Incarnation, pathon ta theia ${ }^{100}$ Hierotheos appears again in chapter 3, where he is presented as having wholly departed himself, exestekos, and communed with the divine things on the

on the New Theologian and Spiritual Fatherhood (Leiden, 1990) Esp. 37-189. On the presence of the ascetic holy man in late antique society, see P. BROwn, The Rise and Function of the Holy Man in Late Antiquity // JRS 62 (1971) 80-101, and P. RousSEAU, Ascetics, Authority, and the Church (Oxford, 1978) Esp. 18-67. On the holy man as «theophanic», see M. S. Burrows, On the Visibility of God in the Holy Man: A Reconsideration of the Role of the Apa in the Pachomian Vitae // VC 41 (1987) 11-33; S. A. Harvey, The Sense of a Stylite: Perspectives on Symeon the Elder // VC 42 (1988) 376-394; A. Orlov, A. Golitzin, «Many Lamps are Lightened from the One»: Paradigms of the Transformational Vision in the Macarian Homilies // VC 55 (2001) 281-298, esp. 292-298; and A. Golitzin, «Earthly Angels and Heavenly Men»: The OT Pseudepigrapha, Nicetas Stethatos, and the Tradition of «Interiorized Apocalyptic» in Eastern Christian Ascetical and Mystical Literature // DOP (forthcoming).

${ }^{98} \mathrm{DN} 2.8,645 \mathrm{C}(132: 11-13)$.

${ }^{99}$ DN 3.1, 680B-D (138:2-139:16), and 680B (138:7-9) on «becoming present» to the Trinity. For Evagrius' On Prayer, see the translations of the Greek text in Nicodemus of the Holy Mountain's Philokalia 1:176-89 (under the name of Nilus of Sinai), and the slightly different MS tradition in $P G 79.1165-1199 \mathrm{C}$, by, respectively, K. T. Ware, P. Sherrard, G. W. Palmer (eds.), The Philokalia: The Complete Text (London, 1979) 1:28-71; and J. E. BAMBERgER, The Praktikos and Chapters on Prayer (Kalamazoo, 1970) 52-80. Note the Evagrian «apophaticism» in On Prayer 67-68, 73-74, and 114-117.

${ }^{100}$ DN 2.9, 648B (134:2). 
occasion of his participation in the funeral of the Mother of God - for which feast, by the way, Dionyius provides us with one of our earlier witnesses (it was very popular in Syria). ${ }^{101}$ In the latter experience, of course, we find mystical ecstasy once again set in a liturgical context, ${ }^{102}$ but I do not think that this takes away from the debt to ascetical literature. Hierotheos" «suffering» in the preceding chapter has no such ecclesiastical context.

\section{The Mystical Theology: Ascending the "Mountain of the Church» to Approach the Light of Christ, the Shekinah}

These remarks brings us at last to the matter of the little treatise called The Mystical Theology, where I think we might do well to pause a moment to consider the meaning of that title, which is Dionysius' own coinage. We do well, too, to bear in mind the fact that the term, mysticism, as used today, is of relatively recent vintage, not much over 300 years old. Anyone approaching this little work in expectations of the sort of detailed, personal accounts of supra-normal experience which one meets in, say, the great Counter-Reformation mystics is going to be disappointed - as was Fr. Jean Vanneste forty years ago. Dionysius delivers nothing of the kind. Does this mean that he was not a «mystic», in our modern sense? It does not. I would myself say that he was writing about something he knew from experience, but I would have to add that this is an opinion which cannot be proven from the text. What is evident, though, and even obvious, is the fact that he believed that such an experience is possible.

This leads me back to the title. «Mystical» for our writer carries essentially its general, patristic meaning. It signifies «hidden», «secret», perhaps with overtones of «spiritual» — as in Origen of Alexandria's phrase, the «mystical sense» of scripture — and «invisible». ${ }^{103}$ What then would a hidden, secret,

${ }^{101}$ DN 3.2, 681D-684A (141:11-14). For bibliography on the feast of the Mother of God's falling asleep, see S. A. HARVEY, Incense Offerings in the Syriac Transitus Mariae: Ritual and Knowledge in Ancient Christianity // The Early Church in its Context: Essays in Honor of Everett Ferguson / Ed. A. J. Malherbe, F. W. Norris, J. W. Thornton (Leiden-Boston-Köln, 1998) 175-191.

${ }^{102}$ Cf. also Isaiah's vision in the Temple, the subject of all of $\mathrm{CH} 13$, and Bishop Carpus' reception of visions prior to celebrating every liturgy, Epistle 8.6, 1097BC (188:11-13), together with Moses' ascent of Sinai in MT 1.3 as freighted with liturgical overtones. On the latter, see RoREM, Moses as the Paradigm of the Liturgical Spirituality of Pseudo-Dionysius...; and Golitzin, Et introibo ad altare dei... 168-177.

${ }^{103}$ See the sources and meanings listed for mystikos in G. W. H. LAMPE, A Patristic Greek Lexicon (Oxford, 1972) 893-894; together with B. McGinn, The Foundations of Christian Mysticism: Origins to the Fifth Century (New York, 1991) Esp. $117 \mathrm{ff}$. 
spiritual or invisible theology be? As a glance at Lampe's Patristic Greek Lexicon will tell us, our current understanding of the word, «theology», as «rational discourse about divine things» stands at the very bottom of a long list of meanings. By contrast, at the top of that list we find the following: 1) God, especially as in the inner life of the Trinity; 2) the experience of God in Trinity, i.e., the mystical (in the modern sense) encounter, also the beatific vision; 3) divine praise, liturgy, as in the worship of: a) the angels, and b) the Church; and 4) the Scripture. ${ }^{104}$ It seems to me that this sequence, including its assignments of relative importance, gives us a pretty good idea of what Dionysius is up to. His subject, I take it, is the life of the Trinity as we may experience it in this life, recalling at the same time his stress on the liturgy and sacraments as supplying the whole context of our life in Christ, and his general attention to the scriptures. Only at the very end, last and least, do we have a technical, philosophically based discussion of the ascent to God, in this instance of the apophatic way or via negativa.

It is therefore no surprise that the $M T$ is - again my favorite word «bracketed» by the Trinity. Dionysius begins and ends with it. The MT opens with a prayer to the «supraessential Trinity», which I quote in slightly amended form from the Paulist Press translation:

Lead us beyond unknowing and light, up to the furthest, highest peak of the mystical scriptures, where the mysteries of theology [recall our discussion just now!] lie simple, absolute, and unchanging in the brilliant darkness [gnophos] of a hidden silence. Amid the deepest shadows they pour out overwhelming light. ${ }^{105}$

Here we should note particularly the terms «silence» (sige) and darkness (gnophos). The latter, based on Exodus 19-20 and 24, will be the term of Moses' ascent two paragraphs later, while the former Dionysius understands as the terminus of all theological discourse, of all our words and images, as indicating that moment when we are, as it were, confonted with God Himself. I shall return to Moses and the darkness in a moment, but for now let me turn rather to the end of the treatise, where Dionysius moves to the application of the via negativa whose theory he has just finished sketching in chapters 2 and 3. He begins in chapter 4 by stating that God is not a body nor anything approachable by the senses (recall the Messalians' claim to a physical sight of the Trinity), ${ }^{106}$ and then addresses the higher, intelligible names of God:

${ }^{104}$ LAMPE, A Patristic Greek Lexicon... 627-628.

${ }^{105}$ MT 1.1, 997A (141-142:3); Pseudo-Dionysius: The Complete Works... 135.

${ }^{106}$ MT 4, 1040D (148). See above and nn. 52-3 for the Messalians. In view of the latter, and more broadly of the pseudepigraphic and apocryphal literature that I understand Dionysius to be confronting, I would see these negations directed against the notions of God having a body, a «place», a «form» (morphe) and «shape» (eidos), 
Moving yet higher, we say that He is... neither soul nor mind; neither has He imagination nor opinion nor reason [logos] nor intuitive knowing [noesis]; neither is He reason nor intuition, neither can He be reasoned nor intuited. He is neither life nor does He live; neither is He essence, nor eternity, nor time... He is neither oneness, nor deity, nor goodness. He is not spirit, as we understand [the term], nor sonship nor fatherhood... He is no one of the things which are not, nor any one of those which are... beyond affirmation... and beyond negation is the transcendence of Him Who, simply, is beyond all things and free. ${ }^{107}$

It may be argued that I have been a little perverse here in choosing to use as pronoun the masculine singular, «He», and in assigning the place of the last word to «free», apolelymenon, when the Greek actually ends with «beyond [epekeina] them all». Both moves are frankly interpretative, that is, intended to emphasize what I take to be Dionysius' central concerns. On the other hand, to use the pronoun «it», as the Paulist Press text does, is itself equally an interpretation, and one which, given the English associations with the neuter pronoun, is inevitably a negative one. ${ }^{108}$ In light of my prior discussion, I think it fair to say that we can dispense with the question mark over Dionysius' Christianity, and thus use «He» both to underline the personal quality of the encounter with God, and, with an eye toward my discussion of the epistles following the $M T$, to point toward Christ. Likewise, I understand «free» to signal the real thrust of these negations. Their point is that God is subject to absolutely none of our conceptions. Even the revealed names Father, Son, and Spirit - are finally icons, images, drawn from human experience in the world. They are, indeed, given us in order to point to a reality in the Godhead, in fact to a divine community, but that community in and for itself escapes definitition altogether. Note, too, Dionysius' careful qualification: «not spirit as we understand [the term]», and recall as well that we have

etc., as quite relevant to Dionysius' readers. These were ancient ideas, based on the biblical throne visions, and, in both Jewish and Christian circles, long-lived. On their presence in Jewish literature roughly contemporary to Dionysius, see for example G. Scholem, Jewish Gnosticism, Merkabah Mysticism, and Talmudic Tradition (New York, 1960) 36-42; and in early Christian literature, G. G. Stroumsa, Form(s) of God: Some Notes on Metatron and Christ // HTR 76.3 (1983) 269-288; together with DeConick, Seek to See Him... Esp. 95-125, and Fossum, Partes Posteriori Dei...

${ }^{107}$ MT 5, 1045D-1048B (149-150).

${ }^{108}$ Note that, although the negations begin in MT 4 and carry on through most of 5 speaking of «the cause of all», he ton panton aitia, admittedly an impersonal phrase and with attendant pronouns in the feminine (for aitia), they conclude with: «the transcendence of him [or «it»] who, simply, is beyond all things and free» (he hyperoche tou panton haplos apolelymenou kai epekeina ton holon), where tou and apolelymenou indicate either a masculine or a neuter genitive singular. I have opted for the former. 
already seen him denying the adequacy of sonship and fatherhood to God in DN 2.8 while discussing «spiritual fatherhood». Again, even the most exalted and refined of our relations with one another are only pointers to a reality which transcends us. They are, surely, «like» God in some sense, but the divine reality is not simply equivalent to our experiences with each other. God can only be known in the experience of His presence, His light, His darkness - in short, in the special kind of «unknowing» which we also saw begin the $D N$.

All this brings me, at long last, to the ascent of Moses in MT 1.3, which I quote at length in my own translation:

Moses is bidden first of all to be purified himself, and then to separate himself... and, after complete purification, he hears the many-voiced trumpets, he beholds many lights... then... with the chosen priests he arrives at the summit of the divine ascents. And yet in these he still meets not with God, for he sees not Him - since He is not to be seen - but the place [topos] where He stands. And this I take to mean the highest and most divine of the things which are seen and grasped by intuitive knowing, which are certain basic principles [logoi] of the things subordinate to Him Who transcends all things, through which His Presence [parousia] is indicated which is above any conception, and which is mounted upon the spiritual summits of His most holy places. And then, abandoning both what is seen and those who see them, he enters into the truly secret darkness [gnophos] of unknowing, according to which he closes [his eyes] to all perceptions open to knowledge, and enters into Him Who is altogether untouchable and invisible and beyond all things. Beyond all things, and belonging to nothing else, whether to himself or to any other, he is, in accordance with what is greater and by a complete cessation of all his own activity of knowing, united to Him Who is wholly unknowable, and by knowing nothing, knows in a manner beyond intellect. ${ }^{109}$

It is difficult for me to say that this is not a properly «mystical» text, whether of Dionysius' own experience or else taken from the experience of others, such as Evagrius, who uses Ex. 24.10 in a very similar way. ${ }^{110}$ Nothing known is God. The notional iconography of the divine names carries us up to «the place where God stands» (so Ex. 24.10 in the LXX), which I understand to mean, on the basis of the Exodus text and its interpretation, to just beneath the divine throne. The one phrase which has given pause to some is the «in accordance with what is greater», kata to kreitton. By this «greater» some-

${ }^{109}$ MT 1.3, 1000C-1001A (143:18-144:15).

${ }^{110}$ For Evagrius' use of Ex 24:10, see esp. the sixty chapters supplementary to his Kephalaia Gnostica edited by W. Frankenberg, Evagrius Ponticus (Berlin, 1912), particularly chps. 2, 21, and 25 (p. 425, 441, and 449), together with letters 29, 33, and esp. 39 (p. 587, 589, and 593). 
thing, Moses is joined to the unknowable God, and with all his own, human activities of mind at a standstill, quiescent. Is this «greater» an inherent faculty? It might be, equivalent in fact to the term, henosis or union, which Dionysius uses elsewhere and seems to understand as the human capacity for receiving God. ${ }^{111}$ If so, however, it is a wholly passive capacity, once more reminiscent of Evagrius Ponticus and the «susceptibility» which the latter sees as the highest faculty of the created intellect, the nous, i.e., that whereby the intellect may become a vessel ready to receive the «light of the Trinity». It is that in us which answers, again in Evagrius as in Dionysius, to the Church's altar. ${ }^{12}$ The last act of the human approach to God is thus an openness, a surrender, in order to enter into the Presence, the parousia in Dionysius' terms, or, as I like to think of it, into the darkness which is at the same time the «unapproachable light» of the Shekinah.

I shall make my reasons for referring to light, and even to the Shekinah, clear in a moment, I hope. For now, let me also recall the discussion above on the liturgy in, particularly, $C H 1.3$ and $E H$ 4.3.12. The liturgical tonality of Moses' ascent, in both the biblical texts themselves and in Dionysius, is or should be obvious. Moses, as Professor Rorem has pointed out, is certainly a type of the dionysian hierarch, of the bishop standing before the altar, ${ }^{113}$ but he is also a type of the Christian soul. The ascensus montis dei is at the same an ingressus ad altare dei, a movement into the living core of the Christian mystery: to Christ in heaven, on the altar, and within the heart. Taken by itself, as it has too often been taken, this passage in tandem with the «nots» of MT 5 might well suggest, as again Professor Rorem thinks is the case, a «loveless» and «christless» mysticism. ${ }^{114}$ And, in fact, the words «Christ», «Jesus», and «love» do not occur at all in the $M T$, so how can I maintain their presence, even if unspoken? I reply that I can, first, because we have already seen in the $\mathrm{CH}$ and, especially, in the $E H$ that Christ, in the Church, is our divine milieu. He is the one in Whom we receive the «eyes of the intellect»

${ }^{111}$ V Anneste, Mystère de Dieu... 183-217; and Y. DE AndiA, Henôsis: l'union à Dieu chez Denys l'Aréopagite...

112 «The intelligible temple is the pure intellect whicn now possesses in itself the Wisdom of God... the temple of God is he who is a beholder of the sacred unity, and the altar of God is the contemplation of the Holy Trinity» (Kephalaia Gnostica V.84 / Ed. A. Guillaumont in $P O 28$, p. 213. Cf. also supplementary chapters 37 and 45 (Frankenberg, Evagrius Ponticus... 459 and 461).

113 «Moses as the Paradigm of the Liturgical Spirituality of Pseudo-Dionysius», SP 18.2 (1989) 275-279. The bishop as Moses, with echoes of Dionysius' MT 1.3, is taken up with delight by Patriarch Germanos of Constantinople in the early eighth century. See St. Germanos on the Divine Liturgy / Tr. P. MEYendorff (Crestwood, NY, 1990) 90-93.

${ }^{114}$ Expressed perhaps most forcefully in his The Uplifting Spirituality of PseudoDionysius... 144. 
and, in Whom, as «our most divine altar», «wholly consumed», we discover our access to God. Second, because that same consummation, on the peak of the «Mountain of the Church», must surely discover its correlate experience here, in the darkness of the mount of revelation and theophany, Sinai, a correlation that we have already met in Ephrem Syrus: the Church as Sinai. Third, Christ is also Himself the myron that consecrates and consumes, the substance of the gift received through the very access which He Himself offers us. Fourth, regarding love, Dionysius has already told us in the $D N$, and at length, that divine eros is the power which returns us all to God. It is thus necessarily that force which drives the ascensus-ingressus of Moses here in the $M T$.

\section{Completing the Context of the Mystical Theology: Epistles I-V and Christ the "Sudden»}

I suggest that the first five epistles of the $C D$ function as a kind of chiasm, and that together they serve to round out and complete the thought of the $M T .{ }^{115}$ Let me proceed according to what I take to be the chiasm, with Epistle 1 matching up with 5, Epistle 2 with 4, and Epistle 3 tying them up and together. Epistle I continues the themes of divine darkness and unknowing which preoccupy the MT: God's transcendent darkness (here skotos) is «hidden by the light of knowledge», Dionysius says, while «complete unknowing is the knowledge of Him Who is known to transcend all things». ${ }^{116}$ Very good, but then this is met and countered by the opening of Epistle V: «The divine darkness [gnophos] is the unapproachable light in which God is said to dwell». ${ }^{117}$ God's dwelling place, katoiketerion, recalls — and not, I think, accidentally - the place of the divine throne which, in the ancient traditions of apocalyptic literature, and in the later Christian apocalypses and apocryphal materials which I mentioned above in connection with the monks (or, for that matter, in the Rabbinic mystical texts of the merkabah, the divine chariot-throne), is always characterized by overwhelming light. Light is both the Presence, the Shekinah Himself, and the stream which proceeds from $\mathrm{Him}^{118}$ Thus we find Dionysius continuing in Epistle V:

${ }^{115}$ I have made this argument before, in Et introibo ad altare dei... 222-227 and, with larger range of supporting texts, in Revisiting the 'Sudden': Epistle III in the Corpus Dionysiacum // SP 37 (2001) 482-491.

${ }^{116}$ Epistle 1, 1065A (156-157).

${ }^{117}$ Epistle 5, 1073A (162:3-4), and cf. DN 7.2, 869A (196:11-12) for the same equation of the gnophos of Sinai with the aprositon phos, «unapproachable light», of I Tim 6:16.

${ }^{118}$ For the fire and/or light of the Presence in the ancient apocalypses, see I Enoch 14:17-22 and 71:2-6; Daniel 7:10; 2 Enoch 20:1 and 22:1; 3 Enoch 36, among Jewish sources, and cf. the Christian Martyrdom and Ascension of Isaiah 8:1-2, 21-26; 
And if it [i.e., the unapproachable light] is invisible because of its superabundant clarity, and unapproachable because of its transcendent outpouring of light, yet is here that everyone who enters [gignetai] who has been made worthy of seeing and knowing God. ${ }^{119}$

He then goes on to cite David and, especially, Paul as examples of this experience. Let me draw our attention to two other points here. First, the «entering into» the divine presence deploys the same verb (gignomai) as Dionysius uses in Epistle X concerning those holy ascetics who, even in this life, «are already with God» (meta tou Theou gignomenous). Second, an ancient marginal note to Epistle $\mathrm{V}$ here will help us in identifying a key theophany to which I believe Dionysius will shortly be alluding in the central Epistle III. On the phrase, «unapproachable light», the scholiast makes the seemingly humdrum observation that the experience of the visio dei might be compared to trying to stare at the sun's disk at noon (mesembria). ${ }^{120}$

The «transcendent outpouring of light» leads us to the matter of God's selfcommunication, which I take to be the subject of both Epistles II and IV. In the former, Dionysius alludes back to a distinction that he had touched on in $D N 2$ and 11, between God in se and ad extra. God truly gives Himself, the Areopagite states in Epistle II, and truly deifies, but, while He is Himself the deifying gift, theopoion doron, He yet transcends all the relations He enters into. He gives of His actions (energeiai) or powers (dynameis), but not of His essence (ousia). ${ }^{121}$ Epistle IV makes it clear that the source of this gift of divine energy or power is Christ. In Jesus, Dionysius tells us, transcendence and immanence (here apophasis and kataphasis, respectively) have met and been joined. Those things, he goes on, «which are affirmed of Jesus' love for humanity preserve the force of transcendent negation». Therefore, he concludes,

and 9:6. On the Rabbis, see again CHERnus, Mysticism in Rabbinic Judaism... 7487, and for personal transformation, W. F. SMELIK, On the Mystical Transformation of the Righteous into Light in Judaism // JSJ 27.2 (1995) 122-144; and in the early Christian Gospel of Thomas, see again (as above, n. 51) A. DeConick, Seek to See Him... For the «blessed light of the Holy Trinity» in Evagrius, see A. GuILlaumont, Les visions mystiques dans le monachisme oriental chrétien // Aux origines du monachisme... 136-147; SÉD, La Shekinata et ses amis araméens... 240-242; BunGE, Nach dem Intellekt Leben?..., and for the same notes in Evagrius' teacher, Gregory of Nazianzus, J. A. McGuckin, Perceiving Light from Light in Light (Oration 31.3): The Trinitarian Theology of Gregory the Theologian // GOTR 39.1 (1994) 7-32.

${ }^{119}$ Epistle 5, 1073A (162:4-6).

${ }^{120} P G$ 4. 536B.

${ }^{121}$ See $D N$ 11.6, 953C-956B (222:3-223:3), and also 5.2, 816C (181:7-15), together with John of Scythopolis' scholion on Epistle II in PG 4.529B-D, where John rightly discerns the importance of Dionysius' distinction between the powers/activities which God shares with us, and the incommunicable essence, for understanding the Areopagite's «deifying gift» in Epistle II. 
[Christ] did not do what is divine as God, nor what is human as man, but instead [as] God having become man, He has administered to [or, arranged for] us a certain, new divine-human activity. ${ }^{122}$

My translation is different from the usual rendering of this text, which applies the «theandric activity» entirely to Jesus, as in the Paulist Press version: «He accomplished something new in our midst - the activity of the God-man». Whether strictly accurate or not, however, it still serves to convey something which Dionysius believes is true and fundamental, and that is that the Incarnation affords us a real participation in God's own actions and gifts. Let us recall the definition of hierarchy, which I quoted earlier from $\mathrm{CH} 3.1-$ 2 , and which included the description of a hierarchy's members as «spotless mirrors of the primordial light». We might add, in $E H$ 1, the reference to Jesus Who «makes our life, disposition, and activity [energeia] something divine». ${ }^{123}$ I could multiply examples, but these will suffice to make my point: Christ's divine-human activity comes even to us, and it does so specifically in the divine polity and way of life - the entheos politeia, as Dionysius puts it elsewhere ${ }^{124}$ - of the Church. It is in the latter that we receive the «deifying gift» mentioned in Epistle II, just as it is in and through the Church that we are led to encounter the mystery of Christ's divinity in a «transcendent outpouring of light».

These several points, together indeed with the entire $C D$ itself, are summed up by the center and «punchline» of the chiasm, Epistle III, which I translate in full:

«Suddenly» means that which comes forth from the hitherto invisble and beyond hope into manifestation. And I think that here the scripture [lit., theology] is suggesting the philanthropy of Christ. The super-essential has proceeded out of its hiddenness to become manifest to us by becoming a human being. But $\mathrm{He}$ is also hidden, both after the manifestation and, to speak more divinely, even within it. For this is the hidden of Jesus, and neither by rational discourse nor by intuition can His mystery [mysterion] be explained. but instead, even when spoken it remains ineffable, and when conceived with the intellect, unknowable [agnoston]. ${ }^{125}$

The first thing we notice is the reprise of the themes we have been discussing: divine unknowability and ineffability, together with the tension between transcendent hiddenness and revelation. Secondly, there is the sacramental echo in the reference to the mysterion of the Incarnation. Christ is the sacrament,

${ }^{122}$ Epistle 4, 1072BC (161:4-10).

${ }^{123}$ EH 1.1, 372AB (63:12-64:6).

${ }^{124}$ For entheos politeia, see EH 2.2.4, 396A (71:5); 3.3.11, 441C (91:23); and Epistle 9, 1113A (206:2).

${ }^{125}$ Epistle 3, 1069B (159:3-10). 
both at the center and terminus of the divine processions to us and to our world, and, simultaneously, the vehicle and goal of our return, or ascent.

The real force and key to the coalescence of Dionysius' thought here lies in the word, «suddenly» (exaiphnes), which opens the epistle. On the one hand, and as has often been noted by modern scholarship, the «sudden» has a long ancestry in the Platonic tradition. Plato himself uses it three times: in the Parmenides to indicate the timeless moment of intersection between the eternal, unmoving realm of the Forms and the world of serial time and flux; again in the Symposium, to signify the end and goal of the ascent of eros to the vision of Beauty; and lastly, in Ep VII of Plato's corpus, for the «sudden» conclusion of the philosopher's quest in, perhaps, the vision of divinity (a passage which is alluded to, in fact, in $\mathrm{CH} 15$ ). All these - eros, beauty, stasis/motion, eternity/time - are also important Dionysian themes. Plotinus, too, in an even closer approximation to the thought of the $C D$, uses the «sudden» in Enneads V.3.17; 5.7; and VI.7.36 to signal the vision of the One in light. I have no doubt that Dionysius was aware of these passages. ${ }^{126}$

It is at this point, however, that modern scholarship has always stopped. It thus remains entirely insensitive to the resonances which the «sudden» has in the scriptures and in later Christian literature, all of which I believe Dionysius also intended to evoke. I have in mind especially four appearances in the NT of the word, exaiphnes, together with certain passages in early ascetical literature and, again, St. Ephrem Syrus. The NT texts are Acts 9.3, 22.6, Lk 2.13, and Mk 13.36. The first two are both descriptions of St. Paul's conversion on the Damascus Road and are functionally identical. I quote from the second: «And it happened that as I was travelling... at around midday [mesembria] a great light from heaven flashed suddenly around me». The light, of course, is Christ, Who sends Paul on to his life's work, the apostolate to the gentiles. I note the themes of light, personal encounter with Christ, the «midday» we saw above signaled by the anonymous scholiast, and, perhaps not least, the mission to the «Greeks». ${ }^{127}$ Luke 2.13 links the «sudden» to the angelic liturgy, the gloria in excelsis, which appears around the shepherds near Bethlehem at the moment of the Incarnation. The fourth text, Mk 13.36,

${ }^{126}$ For discussion of the Platonist background of the «sudden» in Epistle 3, see W. Beierwaltes, Exaiphnes, oder die Paradoxie des Augenblicks // Philosophisches Jahrbuch 84 (1966/67) 271-282; and R. MoRTLEY, From Word to Silence. Vol. II: The Way of Negation (Bonn, 1986) 236-240.

${ }^{127}$ I have encountered the mesembria, «noonday», elsewhere in the ascetical literature in contexts which have overtones of the mystical vision. See, for example, Basil the Great, Longer Rules 2 (PG 31. 909); and Evagrius, Epistle 33 (FrankenBERG, Evagrius Ponticus... 589). I seem to recall a similar use of the word in Gregory of Nyssa, but the precise reference escapes me just now. The scholiast's remark in any case appears to have been rooted in a tradition, perhaps even one based on the story of St. Paul's vision on the road to Damascus. 
occurs at the end of that gospel's eschatological discourse. Be watchful, Christ warns His listeners, lest returning «suddenly», the Master find them sleeping. The NT therefore ties the «sudden» to Christ, light, the angelic liturgy, ascetical «watchfulness», and the eschaton. Surely, this set of associations is at least as important for Dionysius as the ones I listed above from the pagans.

The appearances of the «sudden» which follow from the later Christian literature are not the result of any thorough inquiry on my part. I have made no systematic search, yet each of the following works: the Acts of Judas Thomas (popular in the Syrian Church at least into the sixth century), Athanasius' Life of Anthony, and the works of St Ephrem are all texts with which Dionysius could easily have been familiar. In the third century Acts of Thomas, the «sudden» occurs at the climactic point of the «Hymn of the Pearl», when the speaker encounters the «robe of glory» woven for him in heaven:

But suddenly (Gr. exaiphnes, Syr. men shel'), when I saw it over against me, the splendid robe became like me, as my reflection in a mirror... so that we were two in distinction, and again one in a single form... And the likeness of the King of Kings was completely embroidered all over it... I clothed myself with it, and mounted up to the gate of greeting... I bowed my head and worshipped the splendor of the Father [meaning Christ here] Who had sent the robe to me. ${ }^{128}$

The robe here is the «heavenly double» and «luminous image», familiar from both Jewish and Christian literature, in which the speaker recognizes the form or shape of his own true being. Christ as the «Splendor» (pheggos) of the Father again recalls the Glory and Shekinah traditions, just as the scene itself partakes of the classical patterns of the ascent to heaven in apocalyptic literature. ${ }^{129}$ In the Life of Anthony, the «sudden» occurs early in the narrative, after «the father of monks» has grown weary and battered from his struggles with the demons. Near despair, Anthony cries to God for help and, «suddenly», the roof of the tomb where he is staying opens up and a beam of light descends to surround him. The light is the presence of Christ, Who expells the demons and comforts His champion. ${ }^{130}$

${ }^{128}$ Acta Thomae 112 // Acta Apostolorum Apocrypha / Ed. M. Bonnet (Hildesheim, 1959) II.2, 223:7-13; translation in W. SchneEMELCHER (ed.), New Testament Apocrypha / Trans. R. McL. WILSON (Louisville, 1992) 2:384-385.

${ }^{129}$ For a similar use of the «sudden» (exaiphnes), see the Acta Phillipi // Acta Apostolorum Apocrypha... II.2, 10:26-11:5 (Christ appears «suddenly», more radiant than the sun); and in an early Manichean document, The Cologne Mani Codex: «Concerning the Origin of His Body» / Ed. R. CAmeron, A. J. Davey (Missoula, 1979) 55:12-57:16, pp. 42 and 44 (a «sudden» rapture to heaven). On the latter text as indicative of continuing traditions of apocalyptic asccent in Syro-Mesopotamian Christian and para-Christian circles, see J. C. ReEves, Heralds of that Good Realm: Syro-Mesopotamian Gnosis and Jewish Traditions (Leiden, 1996) 5-30.

${ }^{130}$ Vita Antonii 10; PG 26. 860A. 
St. Ephrem mentions the «sudden» three times to my knowledge, once in his Hymns on Nature and twice in the Paradise Hymns, to which I have already referred several times. In the first, it is Christ Who is the «star of light Who shone forth suddenly» in the Incarnation. ${ }^{131}$ In the Paradise Hymns the «sudden» occurs first in reference to the angelic liturgy. The trisagion of the Seraphim «suddenly» breaks the silence before the Presence in Eden, and, interestingly enough in light of our discussion of Sinai, Ephrem brings up the angelic worship here in parallel to a reference to the thunder of theophany on Sinai. ${ }^{132}$ The second appearance of the «sudden» in the Paradise Hymns, and perhaps the most apposite of all considering our reflections on Dionysius so far, occurs during Ephrem's obviously eucharistic allusion to the supper of the risen Jesus with the two disciples at Emmaus in Luke 24:29-31:

When the disciples eyes were closed, bread too was the key whereby their eyes were opened to recognize the Omniscient One: darkened eyes beheld a vision of joy and were suddenly filled with happiness. ${ }^{133}$

It seems to me, just on the basis of these nine texts, that we have evidence of a certain tradition or at least current in Christian literature which links the «sudden» to Christ, to light, and to both the heavenly and earthly liturgies. ${ }^{134}$ Assuming that Dionysius knew Syriac, there is perhaps an additional play on this word. The Syriac phrase which renders the Greek exaiphnes is men shelya. Men is simply the preposition «from», like the Greek ek. Shelya, on the other hand, has interesting associations. It contains the meanings: «rest», «silence», and «stillness», and is usually connected in Christian Syriac with the hermits,

${ }^{131}$ Ephrem Syrus, de natura 6.7, CSCO 186, 52; ET: K. MCVeY, Ephrem the Syrian: Hymns (New York, 1989) 112.

${ }^{132}$ Hymnen de Paradiso 5.11, CSCO 174, 18:6-11 (men shel on line 7); Brock, Hymns on Paradise... 106.

${ }^{133}$ Ibid. 15.4, 63:3-8 (men shel on line 8); Brock, Hymns on Paradise... 183. I was alerted to the importance of the «sudden» in Ephrem by M. SCHMiDT, Alttestamentliche Typologien in Paradies Hymnen von Ephräm der Syrer // Paradeigmata: Literarische Typologie des alten Testaments / Ed. F. Link (Berlin, 1989) 55-81, here 75 , together with the explicit parallels she draws between Ephrem and Dionysius in 64-55.

${ }^{134}$ M. N. A BochmueHL, Revelation and Mystery in Ancient Judaism and Pauline Christianity (Tübingen, 1990) notes, p. 66, that «the theme of heavenly revelation out of silence is common in ancient Jewish thought», citing in particular the Wisdom of Solomon 18:14-15, which is worth quoting here: «For while gentle silence [hesychou siges] enveloped all things...your all-powerful word [logos] leaped from heaven, from the royal throne, into the midst of the land...» (NRSV). Note the movement of the divine word from the throne, and from silence, into the world. In anticipation of my remarks on the Syriac for «suddenly» below, note as well that the Syriac Old Testament, the Peshitta, has thus the word (melta) moving «from... silence» [men... shelya]. 
as is hesychia in Christian Greek. ${ }^{135}$ It may also, though, be used, as Dionyius' precise contemporary, the distinguished scholar and bishop, Philoxenus of Mabbug, uses it, to signify the divine being or essence. ${ }^{136}$ As a bilingual pun playing off of these several resonances - thus: «from silence», «from stillness», «from the divine being», etc. — the «sudden» fits indeed very well into the intentions and associations of the $C D$, and particularly of the $M T$, which I have been at pains to underline so far. ${ }^{137}$

Here I am reminded of yet another Syrian whose works we know Dionysius knew, Ignatius of Antioch. The latter characterized Christ as the Word Who proceeds from the Father's silence, sige. Ignatius elsewhere offers a remark that, again, echoes some of the themes we touched on in the $M T$ and in the epistles: «It is better to keep silence and to be, than to talk and not to be... He that truly possesses the word of Jesus is able to listen to His silence». ${ }^{138}$ I would therefore suggest that the silence which concludes the $M T$ is neither empty nor impersonal, but instead the presence of the light of Christ.

But I have not yet cited the scriptural text which the scholia of John of Scythopolis tell us Dionysius is actually quoting in Epistle III. This is Malachi 3.1: «And suddenly the Lord Whom you seek will come into His temple, and the Angel of great counsel whom you desire». ${ }^{139}$ The incarnational allusion that John sees in this text is doubtless part of Dionysius' intention, but, given the other resonances of «temple» which we have seen in the course of this essay, the continual coördination between the temple of the liturgical assembly and the temple of the Christian's body and soul, together with the resonances of mystical experience and especially of a theophany of light attached to the word, «sudden», we can surely say that Dionysius intends to signify as well the presence of Christ on the eucharistic altar, His body after

135 See J. Payne Smith, A Compendius Syriac Dictionary (Oxford, 1903, repr. 1990) 580.

${ }^{136}$ See R. Chestnut, Three Monophysite Christologies (Oxford, 1976) 63, n. 2, and 105 for shelya in Philoxenus of Mabbug. In her first example, it denotes the simplicity of the divine essence, and in her second signals the inner condition of the soul - quiet, silence - necessary for the encounter with God.

137 Thus «from the simple divine being» and the «stillness» around the divine throne (cf. the discussion above, n. 134, of Wisdom 18:14-15), hence a reference to the Incarnation, and «from the silence within», and so the mystical perception of the divine Presence.

${ }^{138}$ Ignatius, Magnesians 8 and Ephesians 15. For the Greek text, see the edition by P. CAmelot, Lettres. Martyr de Polycarpe (Paris, 1969) (SC, 10) 86 and 70-72, respectively.

${ }^{139} P G$ 4. 532AB. In fact, the text John cites appears to be conflation of Mal. 3:1 and Isa 9:6 (LXX). The second half of Mal. 3:1 actually reads «and the Angel of the Covenant», unless there is a variant version of which I am unaware. John's version, of course, accentuates the echo of the Incarnation. 
all, together with His visitation - «beyond hope», «ineffable», «unknowable», to cite Epistle III — within the temple of the soul. This, the sudden flash of the «unapproachable light» within, is, I submit, the very content of the gnophos into which Moses ascends in $M T$ 1.3, as well as of the «consummation» and «access» of $E H$ 4.3.12, where Christ is both the way and the goal. Epistle III is the Corpus dionysiacum in concentrated form: christological, liturgical, and mystical. The worship of the heavenly and earthly churches, the experience of the transcendent God, the hope of the Christian, all meet on the altar which is Christ.

\section{A Reply to the Critics: The Revealed «Pattern» of Public Worship and Private Prayer}

The first question mark over my title still stands. The other two do not. My Dionysius is both Christian and mystic, or, regarding the last, is at the very least a theologian who places the mystical encounter at the center of his thought. But, it is fair to ask, is «my» Dionysius the real one? Here I can do no more than suggest, speaking in terms of the historical «sciences» which we have all been obliged to learn from the Germans - wissenschaftlicherweise, as it were - that the hypothesis which offers the best, most rounded and elegant account of the phenomenon under investigation ought to be preferred. I think that my accounting here best matches that description. My Dionysius belongs and contributes to a continuum. On the one hand, we have the long tradition of Christian Platonism, beginning as early as, say, the Epistle to the Hebrews and continuing through Christian Alexandria to the Asia Minor of the Cappadocians, and then going on through Dionysius to Maximus Confessor, John Damascene, and, still further, to the end of the Byzantine era. ${ }^{140}$ Similarly, the ascetico-mystical line begins at or in the setting of Second Temple Judaism, even before Christian origins, carries on in the second and third century texts of, for example, the Thomas tradition, sees its encratism and centrifugal tendencies corrected by other, primarily Syrian ascetics in the fourth century (thus Aphrahat, the Liber, Macarius, and Ephrem), and then runs, again, through Dionysius to Maximus, especially to the latter's profound little treatise, The Mystagogy, which sets out — precisely as Maximus says he is going to do - in explicit fashion nearly all the very same same connections which I have been obliged to tease out of the $C D,{ }^{141}$ and

${ }^{140}$ On the Christian Platonist tradition in the East, if from a Roman Catholic perspective and hence not always especially friendly to certain aspects of Eastern tradition, see the still very useful study by E. von IvankA, Plato Christianus (Einsiedeln, 1964), together with Golitzin, Et introibo ad altare dei... 255-317.

${ }^{141}$ For an account of Maximus' Mystagogy which appears — and quite strikingly so, since it is to the best of my knowledge a wholly independent work - as a near 
then, beyond Maximus, to Symeon New Theologian and Nicetas Stethatos in the eleventh century, and on to Gregory of Sinai and Nicholas Cabasilas in the fourteenth. ${ }^{142}$ Dionysius fits exactly into these two continua. He is «bracketed», to use that word one last time, by tradition on all sides. It was for this reason, far more than for any aura which may have attached to his sub-apostolic pseudonym, that he was accepted so quickly and so wholeheartedly in the East, and especially so by the monks. Put another way, they welcomed in him what they had known already and accepted in others before him. They recognized him for what he was, a spokesman of the Great Tradition. Put more simply still, and, I confess, with a certain measure of glee in the face of all those fuming Germans, the monks have always known better.

I doubt, however, that «my» Dionysius will necessarily convince many of the scholars whose views I covered - very lightly, to be sure - earlier in this essay. Dionysius as an anomaly, a sort of «lonely meteorite» blazing oddly across the night sky of patristic thought, to use an image coined by Fr. Jean Vanneste, is too embedded in the scholarly consensus - to the degree that we can speak of any consensus at all — to be rooted out easily. ${ }^{143}$ Yet the very fact that Dionysius was accepted by contemporaries of the highest stature and intellectual attainment - Severus of Antioch, John of Scythopolis, and the Alexandrian Christian philosopher, John Philoponus, in the sixth century, Maximus Confessor in the seventh, and John Damascene in the eighth, to name but a few of the most prominent - suggests at the least that he was not so odd to them as he seems nowadays to us. To hold in any case that men of the degree of intelligence, learning, and spiritual accomplishment as those whom I have just listed were simply gulled by the pseudonym is frankly ludicrous. They had to have seen something they liked and, to repeat myself, which they recognized. Long-standing scholarly shibboleths have also played their part in modern dismissals of the Areopagite. Here I think especially of

exact duplicate of my reading of Dionysius, particularly on the relation between the $E H$ and $M T$, see A. Louth, Wisdom of the Byzantine Church: Evagrios of Pontos and Maximus the Confessor. 1997 Paine Lectures in Religion (University of MissouriColombia, 1998) Esp. «Apophatic Theology and the Liturgy in St. Maximos the Confessor» 34-45.

${ }^{142}$ See in regard to this chain esp. A. Golitzin, Hierarchy versus Anarchy? Dionysius Areopagita, Symeon the New Theologian, Nicetas Stethatos, and their Common Roots in Ascetical Tradition // SVTQ 39.3 (1994) 131-179; together with the brief sketch of the Dionysian reception in Golitzin, Et introibo ad altare dei... 401413. On the «inner liturgy» in the Byzantine Hesychast, Gregory of Sinai, see M. vaN PARYS, La liturgie du coeur selon saint Grégoire le Sinaïte // Irénikon 51.3 (1978) 312-337, though the author, while citing Maximus' liturgy of the heart (cf. above, n. 141), seems quite unaware of the presence of his theme in the fourth-century Syrians, in Dionysius, and in Symeon and Nicetas.

${ }^{143}$ Vanneste, Is the Mysticism of Pseudo-Dionysius Genuine?... 288-289. 
the nineteenth- and early twentieth-century argument for a «Hellenization» of the Gospel put forward with such force by such scholars as Adolph von Harnack, a thesis which still on occasion, and to no good effect, intrudes into and obfuscates the study of the Early Church. Confessional attitudes have also played a role in the assessment of Dionysius, whether explicitly (Nygren) or implicitly (Rorem), and have in their turn as often obscured the picture as they have illumined it. Put crudely, Dionysius, according to this particular confessional approach, amounts to a kind of justification for the Reformation. More broadly, however, the Dionysian «problem» is itself but one particular instance of a generally prevailing - even today — «occidentalism» in patristic (and, in so far as it retains any theological interests whatever, modern biblical) scholarship, which is to say that Dionysius continues to be read through the lense of the great Western tradition which owes so profoundly to Augustine of Hippo. It is the latter who contributed essentially to that larger Gestalt of Western theology which I touched on in my introduction, a Gestalt which remained fundamentally unaltered in its basic outline even in a setting, such as that of the medieval Schoolmen, where the Areopagite could be heartily welcomed. The result, as I also noted at the beginning of this essay, was a kind of kaleidoscopic splintering and fragmentation of the Corpus dionysiacum into different elements, one or another of which might then be incorporated into the extant form and concerns of Western theology. One had only to rotate the tube, as it were, to find a pattern that would please.

In spite of how my last remarks may appear, I really do not wish to indulge here either in a cheap bout of Augustine-bashing (especially since I have come more and more over the years to appreciate him as one of the great Fathers), or in yet another instance - to borrow from the idiom of Newtonian physics - of an equal and opposing «orientalism». Either or both would be quite as limited and provincial as what I am criticizing here. Indeed, and too typical of much Orthodox literature, this would simply be to engage in a theology of reaction, defensive in mode, condemnatory in tone, no whit better than the sort of polemic, conscious or unconscious, that I am deploring, and in the last analysis little more than a kind of mirror-image opposite of its target. Understandable as such an attitude might be in light of the massive weight - indeed, all-prevailing dominance - of western thought throughout the world, it a remains a futile and sterile self-indulgence. The problem is not with bad will, as it were, on the part of past Dionysian exegetes, including as far back as the Scholastics themselves, but rather that the lense through which they read Christianity itself has been shaped by the Augustinian inheritance. What fits that lense, perhaps especially as it was refined by the Reformers - e.g., the great dichotomies of law and gospel, nature and grace, and the overarching principle of justification by faith - does not really fit Dionysius or, indeed, much of the Christian East, and thus what I do want to do, and what I hope I have at least begun to do, is to enter the plea that we look - really 
look - at a strange (to us) body of theological literature and try to see it anew, to place it in the context for which I believe it was intended. If we do that, and if we make use, exactly, of those same splendid tools which Western scholarship makes available to us (and for which I daily give thanks), then I think we will begin to perceive the lineaments of a Christian accounting of the liturgy, of ascetical striving, of mystical vision, and - above and before all else - of Christ, which, for all the oddity of its rococo vocabulary, should strike us as at once powerful, deeply moving, and - even — strangely familiar.

That familiar element, to put things in a nutshell, derives most basically from the OT traditions of tabernacle and temple, the two classical loci in the Hebrew scriptures of divine presence and theophany. Put, I hope, a little more precisely still, it turns around the «pattern» for divine worship, the tabernacle, which God reveals to Moses as, arguably, the very climax of the Sinai narrative in Ex. 25:9 ff. ${ }^{144}$ Dionysius, quite consciously (see EH 5.1.2-4), applies that «pattern» to both the Christian assembly at worship, and to the Christian soul, and he does so in order to keep both anchored in each other and thus, mutually, in the revelation given once-for-all, ephapax, in Christ. My echoing of Hebrews is intentional here. In the latter's distinction (Heb 10:1) between «shadow» (skia) and «image» (eikon), we can arguably discern the germ of the Areopagitica. In fact, I think we can see a certain fundamental kinship between Dionysius and the whole Pauline corpus, particularly when we bear in mind that the Apostle, as is becoming increasingly clear in at least some recent scholarship, was often confronting claims to visionary authority very much akin to what I have argued here Dionysius was seeking to correct, corral, and finally harness to an ordered and responsible living-out of the Faith: sacramentally based, com-munity-centered, long-suffering, humble, non-judgemental, and suffused with charity. ${ }^{145}$

${ }^{144}$ On the importance of the temple traditions for early Christianity, and working backwards chronologically, see: M. BARKER, On Earth as it is in Heaven: Temple Symbolism in the New Testament (Edinburgh, 1995) Esp. 7-11, 13-25, 61-72; C. R. KoEsTER, The Dwelling of God: The Tabernacle in the Old Testament, Intertestamental Literature, and the New Testament (Washington, DC, 1989); and R. E. Clements, God and the Temple (Philadelphia, 1965).

${ }^{145}$ See, for example, the following: J. A. FitzMEYER, Glory Reflected in the Face of Christ (2 Cor 3:7-4:6) and a Palestinian Jewish Motif // TS 42 (1981) 630-644; J. BLANK, Gnosis und Agape: zur christologischen Struktur paulinischer Mystik // Grundfragen christlicher Mystik / Ed. M. SchMidT, D. R. BAuer (Stuttgart, 1987) 1-13; J. TABOR, Things Unutterable: Paul's Ascent to Heaven in its Greco-Roman, Judaic, and Early Christian Contexts (Lanham, MD, 1986) Esp. 11-21, 83-97; A. Segal, Paul the Convert: The Apostolate and Apostasy of Saul the Pharisee (New Haven, 1990) Esp. 9-22, 34-71; M. Hengel, «Setzte dich zu meiner Rechten!» Die Intronisation Christi zur Rechten Gottes und Psalmen 110:1 // Le trône de Dieu / Ed. M. PHILONENKo (Tübingen, 1993) 108-194; C. R. A. Morray-Jones, Paradise Revisited (2 Cor 12:1-12): The Jewish Mystical Background of Paul's Apostolate // HTR 86.2 and 3 
This places my hero within a tradition extending back into Christian origins. As I have also argued, he was drawing at the same time, and again very consciously, on more proximate Christian sources, notably fourth-century Syrian ascetical literature, whose own roots go back, in all probability, to the earliest forms and sites of Christianity: the Jewish-Christian villages and communities of Aramaic-speaking Palestine. These fourth-century sources as well - from Aphrahat and the Liber Graduum in the Persian empire east of the Tigris, to Ephrem and the Macarian Homilies in Roman Mesopotamia were all likewise struggling with the same issues and drawing on the same or very similar sources in both canonical and extra-canonical literature. ${ }^{146}$ It is in this Syrian, very Semitic context, and with regard to this theme, that is, the working-out of the Christian meaning of «temple», of the locus of theophany, that we are also to place Dionysius' recourse to late Neoplatonism, specifically to the latter's concern to defend «ancient rites» and piety against claims lodged in favor of the autonomous intellect. Overall, I think, at least as judging from his subsequent reception and the use to which he was put in the East, Dionysius' move here - for which he also had precedents in the long history of Jewish (e.g., the Wisdom of Solomon and Philo) and Christian Platonism - was generally understood and applauded. The bottom-line in any event is that he was not - even emphatically not - the proponent of a theologia gloriae in the Lutheran sense. Luther misread him, though I would not particularly blame the great doctor of the Reform for his error. His Dionysius

(1993) 177-217, 265-292; J. M. Scotт, The Triumph of God in 2 Cor 2:14: Additional Evidence of Merkabah Mysticism in Paul // NTS 42 (1996) 260-281; together with a series of articles by M. GouLDER, arguing not for St. Paul as mystic (to which idea Goulder is allergic), but certainly that he is using the vocabulary of, while arguing against, vison and ascent traditions among Jewish-Christians: Sophia in 1 Corinthians // NTS 37 (1991) 516-534; The Visionaries of Laodicea // JSNT 43 (1991) 1539; Vision and Knowledge // JSNT 46 (1994) 53-71; and The Pastor's Wolves: Jewish-Christian Visionaries behind the Pastoral Epistles // NT 38.3 (1996) 242-256.

${ }^{146}$ Aphrahat, whom I have not touched on here, is strikingly insistent throughout his work on the Christian as the temple of God (a point for which I have to thank my student, Ms Stephanie Skoyles of Marquette University), and on internalizing the ascent traditions of the apocalypses. See thus his striking — not to say astounding appropriation of these motifs from apocalyptic and (perhaps) contemporary hekalot literature in the portrait he offers of the transfigured Christian sage who has become himself the locus gloriae and site of the heavenly liturgy, in I. PARISOT (ed.), Aphraatis Sapientis Persae Demonstrationes, Patrologia Syriaca I (Paris, 1894) XIV.35, columns 660:23-665:9. For comment, see J. RAASCH, The Monastic Concept of Purity of Heart and its Sources. Part IV: The Early Monks // StMon 11.2 (1969) 269-314, here 280-281, linking this passage to I Enoch 14; and R. MurraY, Some Themes and Problems of Early Syriac Angelology // V Symposium Syriacum, 1988 / Ed. R. LAVENANT (Rome, 1990) 143-153, here 150-153, who compares it rather to the rabbinicera Sefer Hekalot, or 3 Enoch. 
was, after all, already the product of centuries of prior misconstrual and of consequent mutation. On the other hand, the real (i.e., «my») Dionysius was hardly the advocate of a classically Lutheran theologia crucis, either, but then I cannot think offhand of any figure in the patristic age who would precisely meet that standard. Historical inquiry can do a great deal to clear up our differences, but it cannot simply dissolve them. They remain, yet even so I do not believe that they are enough to justify our dismissal of the Corpus dionysiacum as a passing — or perniciously influential — anomaly.

\section{A Closing Illustration: The Mosaic of the Transfiguration at St. Catherine's, Sinai ${ }^{147}$}

By way of a kind of epilogue, and as relief from academic argument, let me conclude this essay by turning to an artefact constructed within two or three decades of the first public mention of the Dionysian corpus. In the midsixth century, the same emperor who convoked the colloquium of 532, Justinian I, built a fortress monastery in the Sinai at the foot of Jebel Musa, the by-then traditional site associated with the theophanies of Exodus and, in consequence, already a longtime haunt of Christian ascetics. ${ }^{148}$ In the monastery church, imperial artisans assembled several mosaics, including one depicting the Transfiguration. The latter is located in the apse, directly above the altar. Here already, as Jas Elsner has pointed out in a remarkably perceptive essay in his recent book, Art and the Roman Viewer, ${ }^{149}$ we find the assemblage in a single glance of the major Dionysian themes: the God-man Christ in light, the altar of the eucharist, the Sinai of Moses' ascent, the Tabor of the Transfiguration, and the suggestions at once of mystical vision in this life open to the monks (and pilgrims) who form the worshipping body, and of the eschaton.

What I should like particularly to focus on, and which Elsner does not cover, is what I take to be elements from our discussion just now of the Epistles, and especially of Epistle III, reflected in the portrayl of Christ in this

${ }^{147}$ I have deployed the example of the Sinai mosaic in a number of earlier publications: Hierarchy versus Anarchy... 167, n. 148; Et introibo ad altare dei... 228, and at greatest length in «A Contemplative and a Liturgist»: Father Georges Florovsky on the Corpus Dionysiacum // SVTQ 43.2 (1999) 131-161, here 158-161.

${ }^{148}$ For the dating of the mosaic, see V. BENEŠEviČ, Sur la date de la mosaïque de la Transfiguration au Mont Sinai // Byzantion 1 (1924) 145-172; and for an analysis, E. Kitzinger, Byzantine Art in the Making (Cambridge, MA, 1977) 99-104, though the latter has been deepened by Elsner, cited below and n. 150. See also the remarkable photographs of the mosaic available in National Geographic 125.1 (Jan. 1964) 108109 and 111. The last is especially illustrative of my remarks here, as it is taken from an angle looking directly up at the image from the altar, over which the image is centered.

149 J. ElSNER, Art and the Roman Viewer (Cambridge, 1995) 94-125. 
mosaic - which, by the way and to the best of my knowledge, is the prototype for all subsequent Orthodox iconography of the Transfiguration. Christ is depicted clothed in brilliant white and gold. Rays shoot out from His Person to strike Elijah and Moses at His right and left, together with the stunned disciples at His feet - including, as Elsner points out, the figure of Peter, directly below, who is awakening from sleep into mystical vision. With the force of the rays we might also recall the mesembria pointed out by the anonymous Scholiast and certainly presumed in the Christophany to St Paul, as well as the «ray» imagery so generally prominent in the $C D$. In addition, the mandorla around Christ has a curious feature, also usually reproduced in later Byzantine icons. It is banded. At its outer edge a pale shade, roughly the same hue as the rays, its several rings of color grow increasingly dark as we move inwards until, immediately around the Person of Christ, the innermost ring is a midnight blue verging on black. At least two explanations have been proposed for this feature, both of which have a certain cogency. In one, the blue denotes the color of the firmament beneath God's feet in Exodus 24.10, a text which Evagrius takes up in his portrayl of the azure light of the intellect awaiting the descent of the uncreated light of the Trinity. In the other explanation, the mandorla represents both the bright cloud overshadowing the disciples at the Transfiguration, and the dark cloud on Sinai into which Moses enters. I think both of these apply, but I would go further than Elsner, who stops at the $M T$. In the epistles we saw a certain alternation, especially in Epistles I and V, between dark and light. In Epistle III we met the paradox of Christ's sudden manifestation: light, overpowering, coming forth from the depths of silent divinity and, still, hidden even in the manifestation. The Sinai mosaic strikes me, in short, as a portrayl of the exaiphnes. The latter, with its simultaneous evocation, via Malachi 3.1, of the twin temples of the altar and the heart also matches the image, a depiction of mystical vision sited directly over the table of the eucharist. It is, in fact, the $M T$ located at the heart of the EH, with both united in the Person of Jesus. ${ }^{150}$ Whoever, I think, commissioned that image knew his Dionysius very well, indeed.

\begin{abstract}
The article takes the reader on a brief tour of the Dionysian corpus, beginning with tenth epistle, and then proceeding from the Celestial to the Ecclesiastical Hierarchy, touching briefly on the Divine Names, and concluding with the Mystical Theology and the first five epistles.

${ }^{150}$ Thus the point of Louth's essay on Maximus' Mystagogy, cited above, n. 142. Thus: «Apophatic theology as Maximos envisages it... is the realization in the Christian soul of what is accomplished and celebrated in the Church's liturgy» (ibid. 38).
\end{abstract}

